\title{
Echinostoma 'revolutum' (Digenea: Echinostomatidae) species complex revisited: species delimitation based on novel molecular and morphological data gathered in Europe
}

\author{
Simona Georgieva ${ }^{1,2}$, Anna Faltýnková1, Rebecca Brown ${ }^{1,3}$, Isabel Blasco-Costa ${ }^{1,4}$, Miroslava Soldánová1, Jiljí Sitko ${ }^{5}$,
} Tomáš Scholz ${ }^{1}$ and Aneta Kostadinova ${ }^{1 *}$

\begin{abstract}
Background: The systematics of echinostomes within the so-called 'revolutum' group of the genus Echinostoma, which encompasses the type-species E. revolutum and a number of morphologically similar species, has long been controversial. Recent molecular studies indicate the existence of more species than previously considered valid, thus stressing the need for wider taxon sampling from natural host populations. This is especially true for Europe where morphological evidence indicates higher species diversity than previously thought, but where molecular data are virtually lacking. This gap in our knowledge was addressed in the present study through an integration of morphological and molecular approaches in the investigation of a dataset with larger taxonomic and geographical coverage.
\end{abstract}

Methods: More than 20,000 freshwater snails belonging to 16 species were collected during 1998-2012 from various localities in eight countries in Europe. Snail screening provided representative larval isolates for five species of the 'revolutum' group, identified by their morphology. Adult isolates for four species recovered from natural and experimental infections were also identified. Partial fragments of the mitochondrial nad 1 and 285 rRNA genes were amplified for 74 and 16 isolates, respectively; these were analysed together with the sequences of Echinostoma spp. available on GenBank.

Results: Delineation of the European Echinostoma spp. was carried out based on molecular, morphological and ecological data. The large-scale screening revealed infections with five Echinostoma spp., including one new species: E. revolutum (sensu stricto), E. miyagawai, E. paraulum, E. bolschewense and Echinostoma n. sp. The newly-generated nad 1 sequences from Europe fall into six distinct, well-supported, reciprocally monophyletic lineages corresponding to the species identifications based on morphology; this was corroborated by the $28 \mathrm{~S}$ rDNA sequences. The analyses of the total nad 1 dataset provided evidence for 12 monophyletic groups and five singletons, which represent seven described/named species and ten cryptic species-level lineages of Echinostoma.

Conclusion: We conclude that nad 1 should be the first choice for large-scale barcode-based identification of the species of the 'revolutum' group. Our study provides a comprehensive reference library for precisely identified isolates of the European species and highlights the importance of an integrative approach for species identification linking molecular, morphological and biological data.

Keywords: Echinostoma 'revolutum' species complex, Molecular and morphological data, nad1, 28S rDNA, Europe

\footnotetext{
* Correspondence: aneta.kostadinova@uv.es

'Institute of Parasitology, Biology Centre of the Academy of Sciences of the Czech Republic, Branišovská 31, 37005 České Budějovice, Czech Republic

Full list of author information is available at the end of the article
}

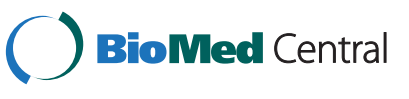

(c) 2014 Georgieva et al.; licensee BioMed Central Ltd. This is an Open Access article distributed under the terms of the Creative Commons Attribution License (http://creativecommons.org/licenses/by/4.0), which permits unrestricted use, distribution, and reproduction in any medium, provided the original work is properly credited. The Creative Commons Public Domain Dedication waiver (http://creativecommons.org/publicdomain/zero/1.0/) applies to the data made available in this article, unless otherwise stated. 


\section{Background}

The systematics of the echinostomes (Digenea: Echinostomatidae) within the so-called 'revolutum' group of the genus Echinostoma Rudolphi, 1809, which encompasses the type-species E. revolutum (Frölich, 1802) and a number of morphologically similar species possessing 37 collar spines, has long been controversial. Problems in defining the species status within this complex include substantial interspecific homogeneity of the morphological characters of both larval and adult stages, inadequate descriptions, poor differential diagnoses and questionable synonymy [1,2] (see Kostadinova \& Gibson [3] for a detailed review).

The 'revolutum' group has been revised twice. Beaver [4] considered only E. revolutum valid, and placed nine species (Distoma echinatum Zeder, 1803, Echinostoma miyagawai Ishii, 1932, E. cinetorchis Ando \& Ozaki, 1923, E. armigerum Barker \& Irvine in Barker, 1915, E. coalitum Barker \& Beaver in Barker, 1915, E. mendax Dietz, 1909, E. paraulum Dietz, 1909, E. columbae Zunker, 1925 and E. limicoli Johnson, 1920) in synonymy and listed additional 11 species as "syn. inq.". Kanev and colleagues [5-7] enlarged the 'revolutum' group to five species, i.e. E. revolutum (syns E. audyi Lie \& Umathevy, 1965, E. ivaniosi Mohandas, 1973, E. paraulum Dietz, 1909 and E. revolutum of Kosupko [8-11]), E. trivolvis (Cort, 1914) (syns E. revolutum of Beaver [4] and E. rodriguesi Hsu, Lie \& Basch, 1968), E. caproni Richard, 1964 (syns E. liei Jeyarasasingam et al., 1972, $E$. togoensis Jourdan \& Kulo, 1981 and E. paraensei Lie \& Basch, 1967), E. jurini (Skvortsov, 1924) (syns E. sisjakowi Skvortzov, 1934, E. orlovi Romashov, 1966 and E. bolschewense (Kotova, 1939)) and E. echinatum (Zeder, 1803) (syns Cercaria spinifera La Valette, 1855, E. lindoense Sandground \& Bonne, 1940, E. barbosai Lie \& Basch, 1966, E. miyagawai of Kosupko [8-11] and E. revolutum of Našincová [12]).

These authors distinguished the five species based mainly on a single morphological feature of their larval stages (the number of outlets of the paraoesophageal gland-cells in the cercaria), the specificity towards the snail first intermediate host (at the familial level), their ability to infect avian or mammalian hosts (or both) and their geographical range on a global scale (continents) (see Kostadinova et al. [1] and Kostadinova \& Gibson [3] for detailed comments). However, E. echinatum cannot be considered valid since this species has not been justified in a taxonomic publication. Further, the re-examination of the voucher specimens from Kanev's experimental studies used in his delimitation of E. revolutum and E. echinatum revealed a number of erroneous identifications including members of the genera Hypoderaeum Dietz, 1909 and Echinoparyphium Dietz, 1909, and a species of Echinostoma with 47 collar spines $[1,13]$.

Kanev [5] favoured the idea of allopatric speciation at a continental scale with only two sympatric combinations: (i) E. revolutum and E. echinatum in Europe and Asia; and (ii) E. trivolvis (recorded as its synonym E. rodriguesi $\mathrm{Hsu}$, Lie \& Basch, 1968), E. caproni (recorded as its synonym $E$. paraensei Lie \& Basch, 1967) and E. echinatum (recorded as its synonym E. lindoense) in South America. This simplistic scheme for the 'revolutum' group has changed since. Based on molecular data, E. revolutum was recorded in Australia [14] and North America [15-17], E. paraensei was re-validated and recorded in Australia and South America [14,18], and as yet unidentified species/cryptic lineages of the group were distinguished in New Zealand, North America and Europe [14-17,19]. Furthermore, a number of species within the group have been described and/or redescribed based on experimental completion of the life-cycles. These include $E$. bolschewense; E. friedi Toledo, Muñoz-Antolí \& Esteban, 2000; E. spiniferum (La Valette, 1855) sensu Našincová [20] and $E$. miyagawai Ishii, 1932 in Europe [1,2,20-22], E. deserticum Kechemir, Jourdane \& Mas-Coma, 2002 in Africa and $E$. luisreyi Maldonado, Vieira \& Lanfredi, 2003 in South America [23,24].

The first molecular study on the problematic 'revolutum' group found very low levels (1.1-3.7\%) of interspecific sequence variation for the nuclear rDNA ITS sequences from isolates of Echinostoma spp. maintained in the laboratory [25]. Morgan \& Blair [26] obtained sequences of the mitochondrial cox 1 and nad1 genes of these isolates and revealed that the nad 1 gene provides a better resolution for investigating relationships within this group in comparison with both ITS and cox1. These authors used nad1 sequences to identify different larval stages of natural echinostome isolates from Australia and New Zealand and reported on the presence of isolates of E. revolutum and $E$. paraensei in Australia, plus five additional unidentified species (with more or less than 37 spines), all referred to as "Echinostoma" and an unknown species closely related to E. revolutum in New Zealand [14]. However, there appeared to be a problem with the identification of the German isolate of E. revolutum used by Morgan \& Blair [14,25,26] (see Sorensen et al. [27] and Kostadinova et al. $[1,2,28])$. Kostadinova et al. [28] completed the life-cycle of E. revolutum in the laboratory and conducted a molecular study using this Bulgarian isolate and a number of European isolates from species of the genera closely related to Echinostoma. These authors provided evidence that the Australian material from Morgan and Blair's study [14] contained species from different genera (Isthmiophora Lühe, 1909, Hypoderaeum and Echinoparyphium; all referred to as "Echinostoma" in GenBank) and that the German and Bulgarian isolates of E. revolutum represent different species [3,28].

Recent molecular studies conducted by Detwiler and colleagues in North America suggested the existence of more than ten species of the genera Echinostoma, 
Echinoparyphium and Hypoderaeum in natural host populations in the USA. These studies confirmed the presence of two species, identified as "E. revolutum" and " $E$. robustum/friedi", and flagged as potentially cryptic taxa divergent lineages for two species, E. trivolvis and "E. robustum/friedi" the USA [16,17]. Recently, Georgieva et al. [19] have shown that the North American isolates of "E. revolutum" studied by Detwiler et al. [16] represent another cryptic species of the 'revolutum' species complex and provided molecular and morphological evidence for an as yet undescribed species of Echinostoma infecting Radix spp. in Germany and Iceland.

In summary, although some of the problems within the 'revolutum' species complex have been tackled, the results of the recent molecular studies stress the need for (i) a wider taxon sampling from natural host populations, especially in Europe where morphological evidence indicates higher species diversity than previously thought, but where molecular data are virtually lacking, and (ii) an integration of molecular, morphological and biological data and taxonomic expertise as a way forward to achieving high resolution and consistency of the identification of Echinostoma spp.

This gap in our knowledge was addressed in the present study through an integration of morphological and molecular approaches in investigation of a dataset with larger taxonomic and geographical coverage. We carried out molecular prospecting (sensu Blouin [29]) for the diversity of the European species of Echinostoma by generating a sequence database linking nad 1 and $28 \mathrm{~S}$ rDNA sequences for larval and adult (experimentally raised and from naturally infected definitive hosts) isolates of Echinostoma spp. These were collected in an extensive sampling programme in eight countries in Europe and identified based on parasite morphology. The inclusion of reliably identified species from Europe in the substantially enlarged nad 1 database and the phylogenetic and distance-based approaches to species delineation applied here further expand the molecular framework for the diversity and distribution of the 'revolutum' group developed by Morgan \& Blair and Detwiler and colleagues that will accelerate the taxonomic revision of this complex of morphologically similar species. Our results considerably enhance the consistency of the identification within this group of cryptic species based on molecular data and thus have implications for both monitoring the diversity and host-parasite relationships of Echinostoma spp. and detecting important pathogens in wild host populations and humans.

\section{Methods}

\section{Sample collection}

More than 20,000 freshwater snails belonging to 16 species [Lymnaea stagnalis (L.), Radix auricularia (L.), R. peregra (Müller), Stagnicola palustris (Müller), Planorbis planorbis
(L.), P. carinatus Müller, Planorbarius corneus (L.), Anisus leucostoma (Millet), A. vortex (L.), Bathyomphalus contortus (L.), Gyraulus albus (Müller), G. acronicus (Férussac), G. crista (L.), Segmentina nitida (Müller), Ancylus fluviatilis Müller and Viviparus acerosus (Bourguignat)] were collected in an extensive sampling programme during 1998-2012 from various localities in eight countries in Europe: Austria, Bulgaria, Czech Republic, Finland, Germany, Hungary, Poland and Slovak Republic. Snails were screened for trematode infections and representative samples of each cercarial isolate (i.e. a group of identical individuals collected from a single host at one point in time [14]) of Echinostoma spp. were examined live and fixed in hot $4 \%$ formaldehyde solution for obtaining metrical data, and in molecular grade ethanol for DNA isolation (see Table 1 for a list of isolates, their hosts, localities and the accession numbers of the sequences). Cercariae were examined live and identified using the data from the relevant primary sources (e.g. Kosupko [9-11]; Našincová [12,21]; Kostadinova et al. [1,2]; Toledo et al. [22] and the keys in Faltýnková et al. [30,31].

Experimental completion of the life-cycle was carried out for two species (E. revolutum sampled in Bulgaria and E. paraulum sampled in Germany) and adult worms were available for morphological identification from the experiments of Našincová $[12,20,21]$ for $E$. bolschewense and Echinostoma n. sp. Sequences were also generated from adult isolates of $E$. revolutum, E. miyagawai and $E$. paraulum recovered from bird definitive hosts in the wild: Anas platyrhynchos (L.) and Aythya fuligula (L.) collected in Poland (vicinities of Gdańsk) and the Czech Republic (vicinities of Tovačov), respectively (see Table 1 for details). All adults were identified prior to sequencing on morphological grounds following Kostadinova et al. [1,2,28].

\section{Sequence generation}

Total genomic DNA was isolated from alcohol-fixed isolates of cercariae or adult worms (posterior fifth of body, the remainder of the worm kept as voucher) using the protocols of Tkach \& Pawlowski [32] or Georgieva et al. [19]. Polymerase chain reaction (PCR) amplifications were performed in $25 \mu \mathrm{l}$ reactions using illustra puReTaq Ready-To-Go PCR Beads (GE Healthcare, UK) containing 2.5 units of puReTaq DNA polymerase, $10 \mathrm{mM}$ Tris- $\mathrm{HCl}$ (pH 9.0), $50 \mathrm{mM} \mathrm{KCl}, 1.5 \mathrm{mM} \mathrm{MgCl}_{2}, 200 \mu \mathrm{M}$ of each dNTP and stabilisers including BSA, 10 pmol of each PCR primer, and 50 ng of genomic DNA.

Partial fragments of the mitochondrial gene nicotinamide adenine dinucleotide dehydrogenase subunit 1 (nad1) gene were amplified using the primers NDJ11 (forward; 5'-AGA TTC GTA AGG GGC CTA ATA-3' [26]) and NDJ2A (reverse; 5'-CTT CAGCCT CAG CAT AAT-3' [28]). The PCR thermocycling profile comprised initial denaturation at $95^{\circ} \mathrm{C}$ for $5 \mathrm{~min}$, followed by 35 cycles $(30 \mathrm{~s}$ denaturation 
Table 1 Summary data for the isolates of Echinostoma spp. used for generation of the new nad1 and 285 rDNA sequences

\begin{tabular}{|c|c|c|c|c|c|c|c|}
\hline \multirow[t]{2}{*}{ Species } & \multirow[t]{2}{*}{ Isolate } & \multirow{2}{*}{$\begin{array}{l}\text { Life- } \\
\text { cycle } \\
\text { stage }\end{array}$} & \multirow[t]{2}{*}{ Host species } & \multirow[t]{2}{*}{ Collection site } & \multirow{2}{*}{$\begin{array}{l}\text { nad1 } \\
\text { haplotype } \\
\text { ID }\end{array}$} & \multicolumn{2}{|c|}{$\begin{array}{l}\text { GenBank accession } \\
\text { number }\end{array}$} \\
\hline & & & & & & nad1 & 28S rDNA \\
\hline E. bolschewense & EBG1 & C & Viviparus acerosus & Danube at Gabčíkovo (Slovakia) & 1 & KP065608 & \\
\hline E. bolschewense & EBG2 & C & Viviparus acerosus & Danube at Gabčíkovo (Slovakia) & 1 & KP065609 & \\
\hline E. bolschewense & EBG3 & C & Viviparus acerosus & Danube at Gabčíkovo (Slovakia) & 1 & KP065610 & \\
\hline E. bolschewense & EBG4 & C & Viviparus acerosus & Danube at Gabčíkovo (Slovakia) & 1 & KP065611 & \\
\hline E. bolschewense & EBG5 & C & Viviparus acerosus & Danube at Gabčíkovo (Slovakia) & 1 & KP065612 & \\
\hline E. bolschewense & EBG6 & C & Viviparus acerosus & Danube at Gabčíkovo (Slovakia) & 1 & KP065613 & \\
\hline E. bolschewense & EBG7 & C & Viviparus acerosus & Danube at Gabčíkovo (Slovakia) & 1 & KP065614 & \\
\hline E. bolschewense & EBG8 & C & Viviparus acerosus & Danube at Gabčíkovo (Slovakia) & 1 & KP065615 & \\
\hline E. bolschewense & EBG9 & C & Viviparus acerosus & Danube at Gabčíkovo (Slovakia) & 1 & KP065616 & \\
\hline E. bolschewense & EBG10 & C & Viviparus acerosus & Danube at Gabčíkovo (Slovakia) & 1 & KP065617 & \\
\hline E. bolschewense & EBG11 & C & Viviparus acerosus & Danube at Gabčíkovo (Slovakia) & 1 & KP065618 & \\
\hline E. bolschewense & EBG12 & C & Viviparus acerosus & Danube at Gabčíkovo (Slovakia) & 1 & KP065619 & \\
\hline E. bolschewense & EBG13 & C & Viviparus acerosus & Danube at Gabčíkovo (Slovakia) & 1 & KP065620 & KP065591 \\
\hline E. bolschewense & EBG14 & C & Viviparus acerosus & Danube at Gabčíkovo (Slovakia) & 2 & KP065621 & KP065592 \\
\hline E. bolschewense & EBG15 & C & Viviparus acerosus & Danube at Gabčíkovo (Slovakia) & 2 & KP065622 & \\
\hline E. bolschewense & EBG16 & C & Viviparus acerosus & Danube at Gabčíkovo (Slovakia) & 2 & KP065623 & \\
\hline E. miyagawai & EMGD1 & A & Anas platyrhynchos & Vicinities of Gdańsk (Poland) & 1 & KP065624 & \\
\hline E. miyagawai & EMT1 & A & Aythya fuligula & Vicinities of Tovačov (Czech Republic) & 1 & KP065625 & \\
\hline E. miyagawai & EML1 & C & Planorbis planorbis & Pond Loužek (Czech Republic) & 2 & KP065626 & \\
\hline E. miyagawai & EML2 & C & Planorbis planorbis & Pond Loužek (Czech Republic) & 2 & KP065627 & \\
\hline E. miyagawai & EML3 & C & Planorbis planorbis & Pond Loužek (Czech Republic) & 3 & KP065628 & \\
\hline E. miyagawai & EML4 & C & Planorbis planorbis & Pond Loužek (Czech Republic) & 3 & KP065629 & \\
\hline E. miyagawai & EML5 & $\mathrm{C}$ & Planorbis planorbis & Pond Loužek (Czech Republic) & 4 & KP065630 & \\
\hline E. miyagawai & EML6 & C & Planorbis planorbis & Pond Loužek (Czech Republic) & 4 & KP065631 & \\
\hline E. miyagawai & EML7 & C & Planorbis planorbis & Pond Loužek (Czech Republic) & 5 & KP065632 & \\
\hline E. miyagawai & EML8 & C & Planorbis planorbis & Pond Loužek (Czech Republic) & 6 & KP065633 & \\
\hline E. miyagawai & EML9 & C & Planorbis planorbis & Pond Loužek (Czech Republic) & 7 & KP065634 & \\
\hline E. miyagawai & EML10 & C & Planorbis planorbis & Pond Loužek (Czech Republic) & 8 & KP065635 & \\
\hline E. miyagawai & EML11 & C & Planorbis planorbis & Pond Loužek (Czech Republic) & 9 & KP065636 & \\
\hline E. miyagawai & EML12 & C & Planorbis planorbis & Pond Loužek (Czech Republic) & 10 & KP065637 & \\
\hline E. miyagawai & EML13 & C & Planorbis planorbis & Pond Loužek (Czech Republic) & 11 & KP065638 & \\
\hline E. miyagawai & EMGD2 & A & Anas platyrhynchos & Vicinities of Gdańsk (Poland) & 12 & KP065639 & \\
\hline E. miyagawai & EMT2 & A & Aythya fuligula & Vicinities of Tovačov (Czech Republic) & 13 & KP065640 & KP065593 \\
\hline E. miyagawai & EML14 & C & Planorbis planorbis & Pond Loužek (Czech Republic) & 14 & KP065641 & \\
\hline E. revolutum (s. str.) & ERBO1 & C & Lymnaea stagnalis & Lake Bodensee (Germany) & 1 & KP065642 & \\
\hline E. revolutum (s. str.) & ERBA1 & C & Lymnaea stagnalis & Pond Bartoňovský (Czech Republic) & 1 & KP065643 & KP065594 \\
\hline E. revolutum (s. str.) & ERVD1 & C & Lymnaea stagnalis & Pond Velký Dvorecký (Czech Republic) & 1 & KP065644 & KP065595 \\
\hline E. revolutum (s. str.) & $\mathrm{ERHH} 1$ & C & Lymnaea stagnalis & Pond Hluboký u Hamru (Czech Republic) & 1 & KP065645 & \\
\hline E. revolutum (s. str.) & ERV1 & C & Lymnaea stagnalis & Pond Vlkovský (Czech Republic) & 1 & KP065646 & \\
\hline E. revolutum (s. str.) & ERV2 & C & Lymnaea stagnalis & Pond Vlkovský (Czech Republic) & 1 & KP065647 & \\
\hline E. revolutum (s. str.) & ERPL1 & C & Radix auricularia & Pond near Tomislawice (Poland) & 1 & KP065648 & \\
\hline E. revolutum (s. str.) & ERBAL1 & C & Lymnaea stagnalis & Lake Baldeneysee (Germany) & 2 & KP065649 & \\
\hline
\end{tabular}


Table 1 Summary data for the isolates of Echinostoma spp. used for generation of the new nad1 and 285 rDNA sequences (Continued)

\begin{tabular}{|c|c|c|c|c|c|c|c|}
\hline E. revolutum (s. str.) & ERV3 & C & Lymnaea stagnalis & Pond Vlkovský (Czech Republic) & 3 & KP065650 & \\
\hline E. revolutum (s. str.) & ERBAL2 & C & Lymnaea stagnalis & Lake Baldeneysee (Germany) & 4 & KP065651 & \\
\hline E. revolutum (s. str.) & $\mathrm{ERH} 1$ & C & Lymnaea stagnalis & Lake Hengsteysee (Germany) & 5 & KP065652 & \\
\hline E. revolutum (s. str.) & ERT1 & A & Aythya fuligula & Vicinities of Tovačov (Czech Republic) & 6 & KP065653 & KP065596 \\
\hline E. revolutum (s. str.) & ERHU1 & C & Lymnaea stagnalis & Lake Huumojärvi, Oulu (Finland) & 7 & KP065654 & \\
\hline E. revolutum (s. str.) & ERHU2 & C & Lymnaea stagnalis & Lake Huumojärvi, Oulu (Finland) & 8 & KP065655 & \\
\hline E. revolutum (s. str.) & ERK1 & C & Lymnaea stagnalis & Pond near Krausenbechhofen (Germany) & 9 & KP065656 & \\
\hline E. revolutum (s. str.) & $\mathrm{ERHH} 2$ & C & Lymnaea stagnalis & Pond Hluboký u Hamru (Czech Republic) & 10 & KP065657 & KP065597 \\
\hline E. revolutum (s. str.) & $\mathrm{ERHH} 3$ & C & Lymnaea stagnalis & Pond Hluboký u Hamru (Czech Republic) & 11 & KP065658 & KP065598 \\
\hline E. revolutum (s. str.) & $\mathrm{ERHH} 4$ & C & Stagnicola palustris & Pond Hluboký u Hamru (Czech Republic) & - & - & KP065599 \\
\hline Echinostoma n. sp. & ENG1 & C & Planorbarius corneus & Danube at Gabčíkovo (Slovakia) & 1 & KP065659 & \\
\hline Echinostoma n. sp. & ENG2 & C & Planorbarius corneus & Danube at Gabčíkovo (Slovakia) & 1 & KP065660 & \\
\hline Echinostoma n. sp. & ENG3 & $C$ & Planorbarius corneus & Danube at Gabčíkovo (Slovakia) & 1 & KP065661 & \\
\hline Echinostoma n. sp. & ENB1 & C & Planorbarius corneus & Pond Bohdaneč (Czech Republic) & 1 & KP065662 & \\
\hline Echinostoma n. sp. & ENV1 & C & Planorbarius corneus & Pond Vlkovský (Czech Republic) & 1 & KP065663 & \\
\hline Echinostoma n. sp. & ENB2 & C & Planorbarius corneus & Pond Bohdaneč (Czech Republic) & 2 & KP065664 & \\
\hline Echinostoma n. sp. & ENB3 & C & Planorbarius corneus & Pond Bohdaneč (Czech Republic) & 2 & KP065665 & \\
\hline Echinostoma n. sp. & $\mathrm{ENHH} 1$ & C & Planorbarius corneus & Pond Hluboký u Hamru (Czech Republic) & 3 & KP065666 & \\
\hline Echinostoma n. sp. & ENV2 & C & Planorbarius corneus & Pond Vlkovský (Czech Republic) & 3 & KP065667 & KP065600 \\
\hline Echinostoma n. sp. & $\mathrm{ENHH} 2$ & C & Planorbarius corneus & Pond Hluboký u Hamru (Czech Republic) & 4 & KP065668 & \\
\hline Echinostoma n. sp. & ENV3 & C & Planorbarius corneus & Pond Vlkovský (Czech Republic) & 4 & KP065669 & \\
\hline Echinostoma n. sp. & ENG4 & C & Planorbarius corneus & Danube at Gabčíkovo (Slovakia) & 5 & KP065670 & \\
\hline Echinostoma n. sp. & ENG5 & C & Planorbarius corneus & Danube at Gabčíkovo (Slovakia) & 6 & KP065671 & \\
\hline Echinostoma n. sp. & ENG6 & C & Planorbarius corneus & Danube at Gabčíkovo (Slovakia) & 7 & KP065672 & \\
\hline Echinostoma n. sp. & ENV4 & C & Planorbarius corneus & Pond Vlkovský (Czech Republic) & 8 & KP065673 & \\
\hline Echinostoma n. sp. & ENHH3 & $C$ & Planorbarius corneus & Pond Hluboký u Hamru (Czech Republic) & 9 & KP065674 & KP065601 \\
\hline Echinostoma n. sp. & ENV5 & C & Planorbarius corneus & Pond Vlkovský (Czech Republic) & 10 & KP065675 & \\
\hline Echinostoma n. sp. & $\mathrm{ENBOH} 1$ & C & Planorbarius corneus & Pond Bohumilečský (Czech Republic) & 11 & KP065676 & \\
\hline Echinostoma n. sp. & ENB4 & C & Planorbarius corneus & Pond Bohdaneč (Czech Republic) & - & - & KP065602 \\
\hline Echinostoma n. sp. & ENV6 & C & Planorbarius corneus & Pond Vlkovský (Czech Republic) & - & - & KP065603 \\
\hline E. paraulum & EPP1 & C & Lymnaea stagnalis & Pond near Poppenwind (Germany) & 1 & KP065677 & \\
\hline E. paraulum & EPP2 & C & Lymnaea stagnalis & Pond near Poppenwind (Germany) & 1 & KP065678 & \\
\hline E. paraulum & EPM1 & C & Lymnaea stagnalis & Nature Reserve Mohrhof (Germany) & 2 & KP065679 & KP065604 \\
\hline E. paraulum & EPT1 & A & Aythya fuligula & Vicinities of Tovačov (Czech Republic) & 3 & KP065680 & KP065605 \\
\hline E. paraulum & EPM2 & C & Lymnaea stagnalis & Nature Reserve Mohrhof (Germany) & 4 & KP065681 & \\
\hline Echinostoma sp. IG & $\mathrm{EIGH}$ & C & Radix auricularia & Lake Hengsteysee (Germany) & 2 & KC618449* & KP065606 \\
\hline Hypoderaeum conoideum & AK44 & C & Lymnaea stagnalis & Pond Bartoňovský (Czech Republic) & - & - & KP065607 \\
\hline
\end{tabular}

*Published by Georgieva et al. [19].

at $94^{\circ} \mathrm{C}, 20 \mathrm{~s}$ primer annealing at $48^{\circ} \mathrm{C}$, and $45 \mathrm{~s}$ at $72^{\circ} \mathrm{C}$ for primer extension), with a final extension step of $4 \mathrm{~min}$ at $72^{\circ} \mathrm{C}$. Partial (domains D1-D3; c. 1,400 nt) 28S rDNA sequences were amplified using primer combinations U178F (5'-GCA CCC GCT GAA YTT AAG-3') and L1642R (5'CCA GCG CCA TCC ATT TTC A-3') [33] or ZX-1 (5'ACC CGC TGA ATT TAA GCA TAT-3') [34] and 1500R
(5'-GCT ATC CTG AGG GAA ACT TCG-3') [35] with the following PCR profile: initial denaturation at $95^{\circ} \mathrm{C}$ for 5 min, followed by 40 cycles $\left(30 \mathrm{~s}\right.$ denaturation at $95^{\circ} \mathrm{C}, 30 \mathrm{~s}$ primer annealing at $55^{\circ} \mathrm{C}$, and $45 \mathrm{~s}$ at $72^{\circ} \mathrm{C}$ for primer extension), and a final extension step of $7 \mathrm{~min}$ at $72^{\circ} \mathrm{C}$.

PCR amplicons were purified using either a QIAquick $^{\mathrm{mm}}$ Gel Extraction Kit or a Qiagen QIAquick ${ }^{\text {Tw }}$ PCR Purification 
Kit (Qiagen Ltd., UK) and sequenced directly for both strands using the PCR primers [plus LSU1200R (5'-CAT AGT TCA CCA TCT TTC GG-3' [33]) for 28S rDNA]. Sequencing was performed on an ABI Prism 3130xl automated sequencer using $\mathrm{ABI}$ Big Dye chemistry (ABI Perkin-Elmer, UK) according to the manufacturer's protocol. Contiguous sequences were assembled and edited using MEGA v6 [36] and submitted to GenBank (accession numbers shown in Table 1).

\section{Alignments and data analysis}

Newly-generated and published nad 1 and $28 \mathrm{~S}$ rDNA sequences for Echinostoma spp. (Table 1; Additional file 1: Table S1) were aligned using Muscle implemented in MEGA v6; nad1 dataset was aligned with reference to the amino acid translation, using the echinoderm and flatworm mitochondrial code [37], but analysed solely as nucleotides (first, second and third positions within the included codons were included in the analyses). Species boundaries were inferred with the application of the Neighbour-Joining (NJ) method using the Kimura's 2 parameter model (K2P) of substitution for pairwise distance calculations with MEGA v6 (1,000 bootstrap replicates) and Bayesian inference (BI) analyses using MrBayes v3.2 [38]. The best-fitting models of nucleotide substitution were estimated prior to BI analyses with jModelTest 2.1.4 [39,40]. These were the general time reversible model, with estimates of invariant sites and gamma distributed among-site rate variation (GTR + I + G) (nad 1 dataset) and Hasegawa-Kishino-Yano model including estimates of invariant sites (HKY + I) (28S rDNA dataset). Log-likelihoods were estimated over $10^{6}$ generations via 4 simultaneous Markov Chain Monte Carlo chains (nchains $=4$ ) with a sampling frequency of 100 . The first $25 \%$ of the samples were discarded (sump burnin $=$ 2,500 ) as determined by the stationarity of $\operatorname{lnL}$ assessed with Tracer v.1.4 [41]; the remaining trees were used to construct the $50 \%$ majority-rule consensus tree and to estimate the nodal support as posterior probability values [42]. Genetic distances (uncorrected p-distance) were calculated with MEGA v6. Non-metric multidimensional scaling (NMDS) ordination performed with Primer v6 software [43] was used to visualise the raw pairwise distances. The significance of the relationship between the mean intra-specific divergence and the number of isolates sequenced was assessed with Spearman's correlation.

In addition to tree-based approaches to species delineation we used the distance-based identification method implemented in the function Species Identifier v1 within the program TAXONDNA [44]. The algorithm performs assignment to the correct species using K2P pairwise distances in comparisons of each sequence against the dataset using the "best close match" criterion. Assignment outcome is considered successful if the sequences exhibiting the lowest genetic distance (closest matches) are conspecific with the query sequence and the distance between the query and closest matches falls below a specified threshold. We used a distance threshold of 3\%, which is a more conservative estimate than the two threshold values calculated after Meier et al. [44], i.e. $0.84 \%$ (distance below which $95 \%$ of all pairwise comparisons are found; $\mathrm{n}=825$ ) and $2.74 \%$ (distance below which $99 \%$ of all pairwise comparisons are found; $\mathrm{n}=1,631$ ). Relationships between haplotypes of $E$. revolutum sensu lato (s.l.) from Europe and North America were visualised with haplotype networks constructed with statistical parsimony analysis using TCS version 1.21 [45].

\section{Species delineation}

Delineation of the European species of Echinostoma was based on the integration of molecular, morphological and ecological data: (i) support for reciprocal monophyly in the nad 1 phylogeny (a conservative approach to species delimitation); (ii) pairwise divergence at nad1 (including distance-based assignment) and 28S rRNA genes; (iii) matching of sequences for larval and adult stages (three of the species); (iv) comparisons with already published sequences; (v) morphological characterisation and identification of the cercarial and adult isolates; (vi) inference from the experimental completion of life-cycles (all five species); (vi) the use of different first intermediate hosts.

\section{Results}

\section{Infections in natural host populations}

The large-scale screening of natural snail populations in Europe revealed infections with five Echinostoma spp., including one species new to science: $E$. revolutum (type-species), E. miyagawai, E. paraulum, E. bolschewense and Echinostoma n. sp. Considering the recent results of Georgieva et al. [19] who delineated another putative new species (Echinostoma sp. IG), eight snail species are found to be infected with Echinostoma spp. in Europe, namely the lymnaeids Lymnaea stagnalis, Radix auricularia, R. peregra and Stagnicola palustris; the planorbids Planorbis planorbis, Anisus vortex and Planorbarius corneus; and the viviparid Viviparus acerosus. Five species acted as hosts of a single species of Echinostoma: A. vortex (E. miyagawai), S. palustris (E. revolutum), $P$. planorbis (E. miyagawai), $P$. corneus (Echinostoma n. sp.) and V. acerosus (E. bolschewense) and three lymnaeids hosted two Echinostoma spp. each: $L$. stagnalis (E. revolutum and E. paraulum), $R$. auricularia and $R$. peregra (E. revolutum and Echinostoma sp. IG) (see also [19]). Echinostoma revolutum exhibited the widest host range being recovered in the four lymnaeids studied (L. stagnalis, $R$. auricularia, $R$. peregra and S. palustris). 
All cercariae exhibited characteristic features of the species belonging to the 'revolutum' species complex of Echinostoma: (i) 37 collar spines with an arrangement 56-15-6-5 (5 angle and 6 lateral spines on each side and 15 dorsal spines in a double row); (ii) tail with a tip forming a highly contractile attenuated process and seven prominent tegumental fin-folds ( 2 dorsal, 3 ventral and 2 ventrolateral); and (iii) a flame-cell formula $2[(3+3+3)+$ $(3+3+3)]=36$ [19]. However, detailed examination of cercarial morphology revealed specific differences with respect to a combination of characters, i.e. the number and distribution of the penetration and para-oesophageal gland-cells and the structure of the tail fin-folds (see Faltýnková et al. [46]).

Adult isolates representing four species were identified, three (E. revolutum, E. miyagawai and E. paraulum) recovered from naturally infected Aythya fuligula and Anas platyrhynchos and experimentally-raised specimens of E. revolutum and E. paraulum. In both lifecycle experiments the nad 1 sequences of the adults were identical with the sequences of the cercariae used as starting material for infection (see also [28]). Morphological descriptions and sequences for Echinostoma sp. IG based on cercarial isolates sampled in Germany and Iceland have been published recently (Georgieva et al. [19]; see also Additional file 1: Table S1 for details). Formal description of this putative new species awaits the discovery of the adult stage. Detailed descriptions of the life-cycle stages of Echinostoma spp. from Europe and formal naming of the new species reported here will be published elsewhere [46], in order to avoid nomenclatural problems due to uncertainty concerning the first publication of the name.

\section{Novel molecular data from Europe}

Our study generated 74 novel partial nad 1 sequences for five of the six European species of Echinostoma included in the analyses; these were collapsed into 39 unique haplotypes. Considering the sequences generated by Kostadinova et al. [28] and Georgieva et al. [19], the European nad1 dataset for Echinostoma spp. represented a total of 88 sequences and 50 unique haplotypes. Twenty haplotypes were identified in isolates of E. revolutum from four snail host species [L. stagnalis (ten haplotypes), $R$. auricularia (four haplotypes), R. peregra (seven haplotypes) and $S$. palustris (one haplotype)] with wide distribution in Germany (five localities), Czech Republic (four localities), Poland, Iceland, Finland and Bulgaria (one locality each) (Table 1; Additional file 1: Table S1). There was no differentiation within Europe (Table 2) with identical haplotypes shared across localities separated by as much as $2,500 \mathrm{~km}$ (haplotype 1, the most abundant haplotype found in L. stagnalis and Radix spp; see Table 1 and Additional file 1: Table S1).
Although most of the isolates of E. miyagawai originated from a single locality in the Czech Republic, we found high haplotype diversity (14 haplotypes). Notably, one haplotype was shared between adult isolates ex An. platyrhynchos from Poland and Ay. fuligula from the Czech Republic, " $E$. revolutum Germany, Europe" (AF025832) of Morgan \& Blair [14,26] and E. friedi (Valencia, Spain; AJ564379), i.e. across localities separated by as much as $2,200 \mathrm{~km}$. In contrast, E. bolschewense, a species that was also sampled at a single locality, was represented by two haplotypes; the most common haplotype $(n=13)$ was found at three closelylocated sites within two different years.

Eleven haplotypes were identified from isolates of Echinostoma n. sp.; the most common haplotype was shared between locations in Slovakia (Gabčíkovo) and both northern (Pond Bohdaneč) and southern (Pond Vlkovský) locations in the Czech Republic. The two under-sampled (presumably rare) species, Echinostoma sp. IG and E. paraulum, were represented by three and four haplotypes, respectively. One haplotype of Echinostoma sp. IG was shared between cercarial isolates from $R$. peregra in Iceland and Wales, UK (AY168937), the latter provisionally identified on the basis of cercarial morphology as $E$. cf. friedi by Kostadinova et al. [28].

\section{Phylogeny-based species delimitation}

Both NJ and BI analyses resulted in consensus trees with similar topologies. Figures 1 and 2 represent the hypothesis for the relationships within the 'revolutum' complex inferred from genetic distances (with indication of the nodal support from the BI analysis) of the nad1 dataset (159 sequences, $475 \mathrm{nt}$ ) that incorporated the sequences published by Morgan \& Blair [14,26] $(\mathrm{n}=11)$, Detwiler et al. $[16,17](\mathrm{n}=43)$, Georgieva et al. [19] $(\mathrm{n}=14)$ and Kostadinova et al. [28] ( $=2)$; two otherwise unpublished sequences [AJ564379 (E. friedi) and AJ564378 (E. caproni)] of Marcilla et al. available on GenBank were also included in the analyses. NJ and BI analyses produced congruent results with minor topological differences. Six of the previously recognised species/cryptic lineages were represented by singletons thus preventing calculation of bootstrap support; however, most of these formed independent branches on the $\mathrm{NJ}$ and $\mathrm{BI}$ trees (Figures 1 and 2).

The newly-generated sequences from Europe fall into six distinct well-supported reciprocally monophyletic lineages corresponding to the species identifications based on morphology: E. revolutum ex L. stagnalis, $R$. auricularia, $R$. peregra, S. palustris and Ay. fuligula; E. miyagawai ex $P$. planorbis, An. platyrhynchos and Ay. fuligula; E. paraulum ex L. stagnalis and Ay. fuligula; E. bolschewense ex V. acerosus; Echinostoma sp. IG ex R. auricularia and R. peregra; and Echinostoma n. sp. ex P. corneus. Three species, Echinostoma sp. IG, E. bolschewense and E. deserticum 
Table 2 Mean percent intraspecific (along the diagonal) and interspecific divergence (below the diagonal) for Echinostoma spp. in the nad1 dataset and number of pairwise nucleotide differences for 285 rDNA sequences (above the diagonal)

\begin{tabular}{lllllllllllllllll}
\hline & $\mathbf{1}$ & $\mathbf{2}$ & $\mathbf{3}$ & $\mathbf{4}$ & $\mathbf{5}$ & $\mathbf{6}$ & $\mathbf{7}$ & $\mathbf{8}$ & $\mathbf{9}$ & $\mathbf{1 0}$ & $\mathbf{1 1}$ & $\mathbf{1 2}$ & $\mathbf{1 3}$ & $\mathbf{1 4}$ & $\mathbf{1 5}$ \\
\hline $\mathbf{1}$ & E. bolschewense & $\mathbf{0 . 0 7}$ & $12-13$ & $11-12$ & 18 & $11-12$ & $13-16$ & 12 & 8 & - & - & - & 13 & - & - & - \\
$\mathbf{2}$ & Echinostoma n. sp. & 16.5 & $\mathbf{0 . 5 3}$ & $3-4$ & 10 & $3-4$ & 13 & 4 & 7 & - & - & - & 5 & - & - & - \\
$\mathbf{3}$ & E. miyagawai & 16.5 & 14.0 & $\mathbf{0 . 8 3}$ & 9 & $3-4$ & 10 & 13 & 11 & - & - & - & 7 & - & - & - \\
$\mathbf{4}$ & E. revolutum (s. str.) (Europe) & 14.3 & 13.0 & 11.4 & $\mathbf{0 . 8 3}$ & $9-10$ & 15 & 12 & 13 & - & - & - & 13 & - & - & - \\
$\mathbf{5}$ & E. paraulum & 15.8 & 15.1 & 10.8 & 12.6 & $\mathbf{0 . 5 5}$ & $13-16$ & $5-6$ & $6-7$ & - & - & - & $6-7$ & - & - & - \\
$\mathbf{6}$ & Echinostoma sp. IG & 19.3 & 18.9 & 19.0 & 18.2 & 19.4 & $\mathbf{0 . 3 2}$ & 13 & 11 & - & - & - & 16 & - & - & - \\
$\mathbf{7}$ & E. paraensei & 17.0 & 12.6 & 15.9 & 14.9 & 15.3 & 19.3 & $\mathbf{0 . 2 1}$ & 8 & - & - & - & 5 & - & - & - \\
$\mathbf{8}$ & E. caproni & 18.0 & 15.3 & 14.4 & 15.0 & 14.8 & 19.3 & 14.6 & $\mathbf{1 . 8 2}$ & - & - & - & 9 & - & - & - \\
$\mathbf{9}$ & "E. robustum/friedi" Lineage A & 16.9 & 13.9 & 4.9 & 11.3 & 10.8 & 17.3 & 15.3 & 14.0 & - & - & - & - & - & - & - \\
$\mathbf{1 0}$ & "E. robustum/friedi" Lineage C & 15.7 & 13.3 & 9.2 & 10.9 & 10.2 & 18.9 & 13.6 & 14.2 & 8.4 & - & - & - & - & - & - \\
$\mathbf{1 1}$ & "E. robustum/friedi" Lineage D & 16.9 & 13.1 & 8.4 & 12.2 & 10.6 & 19.1 & 14.7 & 15.4 & 8.6 & 5.3 & - & - & - & - & - \\
$\mathbf{1 2}$ & E. trivolvis Lineage A* & 16.3 & 11.8 & 14.6 & 13.0 & 14.7 & 18.0 & 13.6 & 14.3 & 14.1 & 12.7 & 12.9 & $\mathbf{0 . 8 0}$ & - & - & - \\
$\mathbf{1 3}$ & E. trivolvis Lineage B & 15.6 & 12.7 & 15.2 & 14.0 & 15.8 & 19.6 & 14.3 & 16.6 & 14.9 & 14.0 & 13.0 & 8.1 & $\mathbf{0 . 9 1}$ & - & - \\
$\mathbf{1 4}$ & E. trivolvis Lineage C & 14.4 & 11.2 & 15.5 & 13.5 & 15.8 & 19.0 & 14.1 & 16.6 & 15.6 & 13.2 & 13.0 & 7.9 & 2.7 & $\mathbf{0 . 4 6}$ & - \\
$\mathbf{1 5}$ & "E. revolutum" (USA) & 15.2 & 13.2 & 12.0 & 5.9 & 13.3 & 18.8 & 15.6 & 14.4 & 11.8 & 11.7 & 13.5 & 13.9 & 14.6 & 13.6 & $\mathbf{0 . 8 8}$ \\
\hline
\end{tabular}

*28S rDNA sequence (AY222246) published as E. revolutum by Olson et al. [47].

(a laboratory strain from Niger maintained by Dr J. Jordane (France) with sequences previously reported as Echinostoma sp. I by Morgan \& Blair $[14,25,26])$, appeared with maximum support as the earliest species to diverge among the 'revolutum' group. The remaining species/ lineages formed two main clades (A and B), shown in Figures 1 and 2, respectively.

The first clade (A) comprised the isolates of E. revolutum sensu lato (s.l.), Echinostoma sp. NZ-Ad, E. paraulum, $E$. miyagawai and the three lineages (labelled A-C) of " $E$. robustum/friedi" sensu Detwiler et al. [16,17] (Figure 1). Within this clade, the isolates ex Stagnicola elodes from the USA labelled as "E. revolutum" by Detwiler et al. $[16,17]$ and the European isolates from four species of lymnaeids and wild and experimentally raised adults identified by us as E. revolutum sensu stricto (s. str.) based on morphology (see also [28]), formed sister reciprocally monophyletic lineages (Figure 1) with high support (as in Georgieva et al. [19]). The average sequence divergence between the two lineages was $5.9 \%$ and there were no shared haplotypes; the average intra-lineage divergence was low ( 0.88 and $0.83 \%$, respectively; Table 2 ). Maximum parsimony haplotype network analysis depicted two unconnected networks at $95 \%$ connection limit for the isolates of E. revolutum (s.l.) from Europe and the USA (Figure 3). These results strongly support the suggestion of Georgieva et al. [19] that the North American isolates of "E. revolutum" of Detwiler et al. [16,17] represent a distinct cryptic species of the 'revolutum' group.

The European cercarial and adult isolates of E. miyagawai clustered together with: (i) one North American isolate (GQ463053), Lineage A of "E. robustum/friedi" sensu Detwiler et al. [16,17]; (ii) the isolate "E. revolutum Germany, Europe” (AF025832) of Morgan \& Blair [14,25,26]; (iii) three Australian isolates (AF026286AF026288) identified as E. revolutum by Morgan \& Blair [14] and representing Lineage B of "E. robustum/friedi" sensu Detwiler et al. [16,17]; and (iv) the isolate of $E$. friedi of Marcilla et al. (AJ564379; sequence otherwise unpublished). The isolates (ii) and (iv) shared the most common haplotype of E. miyagawai from Europe thus confirming their conspecificity. When the North American isolate (i) was considered separately, the average intraspecific divergence for E. miyagawai was $0.83 \%$ and the average divergence between this isolate and E. miyagawai was 4.9\% (range 4.2-5.3\%) (Table 2). Surprisingly, the North American "E. robustum/friedi" of Detwiler et al. [16] was recovered as paraphyletic with lineages $C$ and $D$ divergent from Lineages A and B (i and iii above) (Figure 1) and comprising a pair of sister taxa that exhibited a strongly supported sister-group relationship with the European $E$. paraulum in the BI analysis.

The second clade (B) was characterised by maximum support at almost all nodes and comprised isolates of Echinostoma n. sp., E. paraensei and the isolates of the three lineages $(\mathrm{A}-\mathrm{C})$ of $E$. trivolvis identified by Detwiler et al. $[16,17]$, joined by three isolates of E. caproni (NJ analysis only; Figure 2). There was poor support for Lineage $\mathrm{C}$ of $E$. trivolvis in the BI tree.

Overall, the analyses of the nad 1 dataset provided evidence for 12 monophyletic groups and five singletons, which represent seven described/named species 


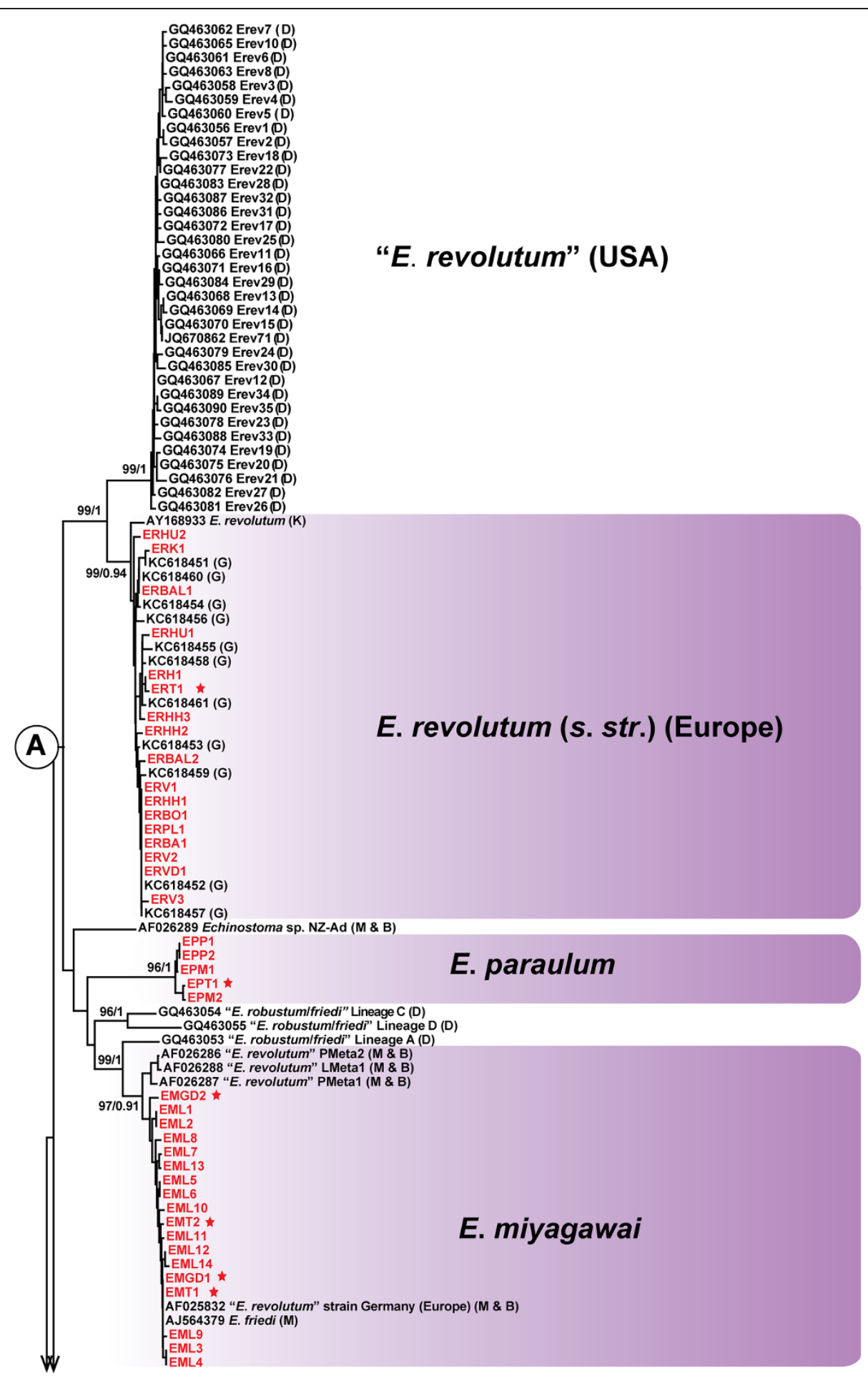

Figure 1 Neighbour-Joining (NJ) tree for 16 species-level lineages within the 'revolutum' group of Echinostoma based on the mitochondrial gene nad1: Clade A. Based on a 475-nt fragment of nad1. Outgroups: Echinoparyphium aconiatum and Hypoderaeum conoideum. Numbers represent node supports from NJ and Bayesian inference (50\% majority rule consensus tree) analyses (only values greater than 70 and 0.95, respectively, are shown). The newly-sequenced European isolates are shown in red; stars indicate adult isolates from natural infections. Sequence identification is as in GenBank, followed by a letter: D, Detwiler et al. [16,17]; G, Georgieva et al. [19]; K, Kostadinova et al. [28]; M, Marcilla et al. (unpublished); M \& B, Morgan \& Blair [14,26]. The scale-bar indicates the expected number of substitutions per site. 


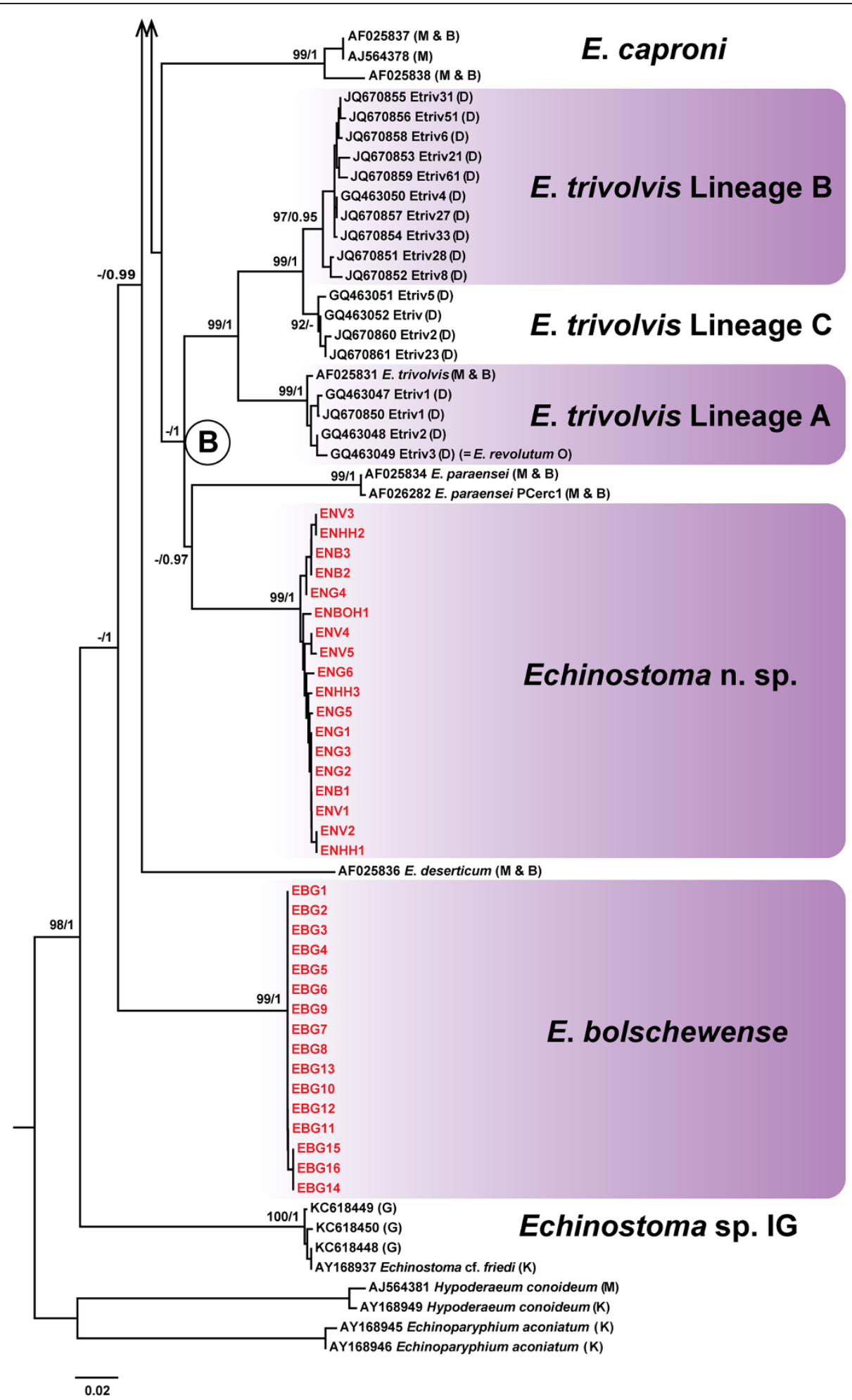

Figure 2 Neighbour-Joining ( $\mathrm{NJ}$ ) tree for 16 species-level lineages within the 'revolutum' group of Echinostoma based on the mitochondrial gene nad1: Clade B and the remaining species, continuation of Figure 1. The newly-sequenced European isolates are shown in red; stars indicate adult isolates from natural infections. Sequence identification is as in GenBank, followed by a letter: D, Detwiler et al. [16,17]; G, Georgieva et al. [19]; K, Kostadinova et al. [28]; M, Marcilla et al. (unpublished); M \& B, Morgan \& Blair [14,26]; O, Olson et al. [47]. The scale-bar indicates the expected number of substitutions per site. 


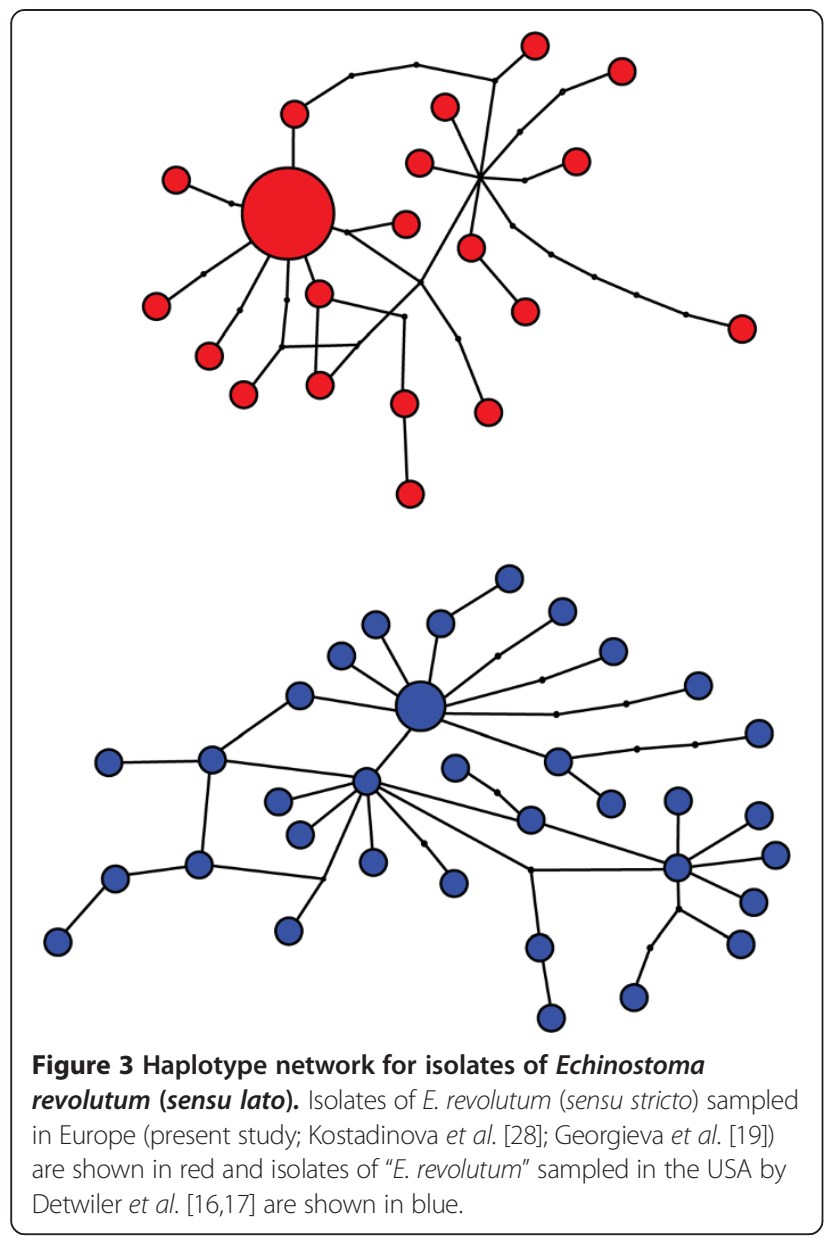

of Echinostoma, i.e. E. revolutum (s. str.), E. bolschewense, E. caproni, E. deserticum, E. miyagawai, E. paraensei and E. paraulum), and ten cryptic species-level lineages: Echinostoma n. sp. and Echinostoma sp. IG from Europe; "E. revolutum", three lineages (A-C) of E. trivolvis (s.l.) and three lineages (A, C and D) of "E. robustum/friedi" sensu Detwiler et al. [16,17] from the USA; and Echinostoma sp. from New Zealand. Notably, the identification of the newly-sequenced adult isolates based on morphology alone, using the concept of Kostadinova et al. [1,2,28] for E. revolutum (s. str.), E. miyagawai and E. paraulum, matched the identification using molecular data.

The 16 newly-generated 28S rDNA sequences corroborated with strong support the distinct species status of the six nad 1 lineages of Echinostoma spp. studied in Europe (Figure 4). The only supported sister-group relationship was between E. revolutum and Echinostoma sp. IG but this is likely due to the incomplete taxon sampling for the 28S rRNA gene. No intraspecific variation was detected for species with multiple sequences, i.e. $E$. revolutum, Echinostoma n. sp. and E. bolschewense, and the two sequences (from one cercarial and one adult isolate) for E. paraulum differed at a single nucleotide position. The lower divergence range was 3-5 nucleotide positions (0.25-0.41\%) between Echinostoma n. sp. and E. paraulum, E. trivolvis, E. miyagawai and E. paraensei; E. paraulum and E. miyagawai; and E. paraensei and E. trivolvis and E. paraulum (see Table 2 for details).

\section{Distance-based species delimitation}

The NMDS two-dimensional plot based on raw pairwise divergence data for all isolates with indication of the content of the two main clades discussed above is presented in Figure 5. The mean intraspecific divergence within the nad 1 dataset was $0.81 \%$ (S.D. $=0.57 \%$; range for mean divergence values of $0.21-1.82 \%$; range for raw values of $0-3.59 \%$, with just four comparisons exceeding $3 \%$; see Table 2). These values were much lower than the mean divergence of $13.3 \%$ (S.D. $=3.1 \%$ ) in the interspecific comparisons (range for mean divergence values of 2.7-19.6\%; range for raw divergence values of 4.2-21.5\%). There was no significant correlation between the number of isolates per species/lineage and mean intraspecific variation (Spearman's rho $=0.248 ; P>0.05$ ). The mean interspecific divergence was 16 -fold higher than mean intraspecific divergence but three sister-species groups $[E$. trivolvis Lineages A-C; E. miyagawai - "E. robustum/ friedi" Lineage A; E. revolutum (s. str.) (Europe) - "E. revolutum" (USA)] exhibited ratios at the margin or below the '10× rule' proposed by Hebert et al. [48], thus indicating a possible problem of overlapping variability at $\operatorname{nad} 1$ in the 'revolutum' species complex (see also Figure 5). However, there was no overlap in the distributions of intraspecific and interspecific (sister-taxa only) divergences (Figure 6). Furthermore, all sister-species groups could be resolved using diagnostic nucleotide sites: 65 for Echinostoma n. sp. - E. paraensei; 44 and 47 for E. paraulum - "E. robustum/friedi" Lineages C and D of Detwiler et al. [16], respectively; 28 for $E$. trivolvis Lineage A $-E$. trivolvis Lineages B and C; 24 for "E. robustum/friedi" Lineage C "E. robustum/friedi" Lineage D of Detwiler et al. [16]; 19 for E. revolutum (s. str.) - "E. revolutum" (USA); and 16 for E. miyagawai - "E. robustum/friedi" Lineage A of Detwiler et al. [16]. Finally, excluding singletons, successful identification of all isolates was achieved for all 12 species/lineages at $3 \%$ divergence threshold in Species Identifier v.1.

\section{Discussion}

The phylogenetic analyses depicted 17 genetically distinct lineages within the data set studied and, excluding singletons, successful identification of all isolates was achieved by the distance-based identification method implemented in Species Identifier v.1 for all 12 species/lineages. Our results are congruent with the phylogenies obtained by Detwiler et al. $[16,17]$ on datasets dominated by isolates from the USA. The increase in the estimated 


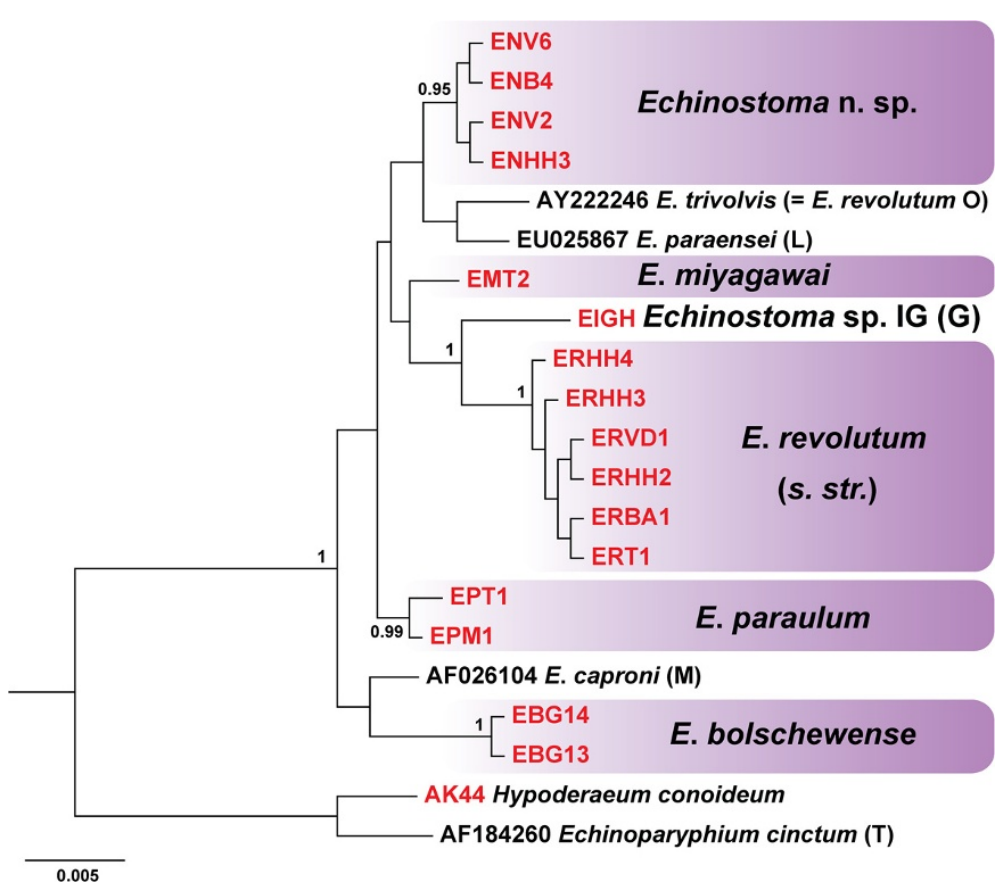

Figure 4 Bayesian inference phylogram reconstructed using partial 28S rDNA sequences for nine Echinostoma spp. The alignment comprised 1,219 nucleotide positions. Outgroups: Hypoderaeum conoideum and Echinoparyphium cinctum. The newly-sequenced European isolates are shown in red. Sequence identification is as in GenBank, followed by a letter: G, Georgieva et al. [19]; O, Olson et al. [47]; L, Lotfy et al. [49]; M, Mollaret et al. [50]. The scale-bar indicates the expected number of substitutions per site.

number of species in the 'revolutum' group is largely due to the increased sampling within Europe. The novel sequence data generated here in association with the morphological characterisation of the life-cycle stages of Echinostoma spp. provides an integrative framework for future studies on species diversity within this difficult group.

\section{European species within the 'revolutum' group}

This first large-scale sequencing study of species of Echinostoma across Europe provided evidence for six molecularly distinct species of the 'revolutum' group. Their independent status was supported by the concordant signal of the mitochondrial nad 1 and nuclear $28 \mathrm{~S}$ rRNA

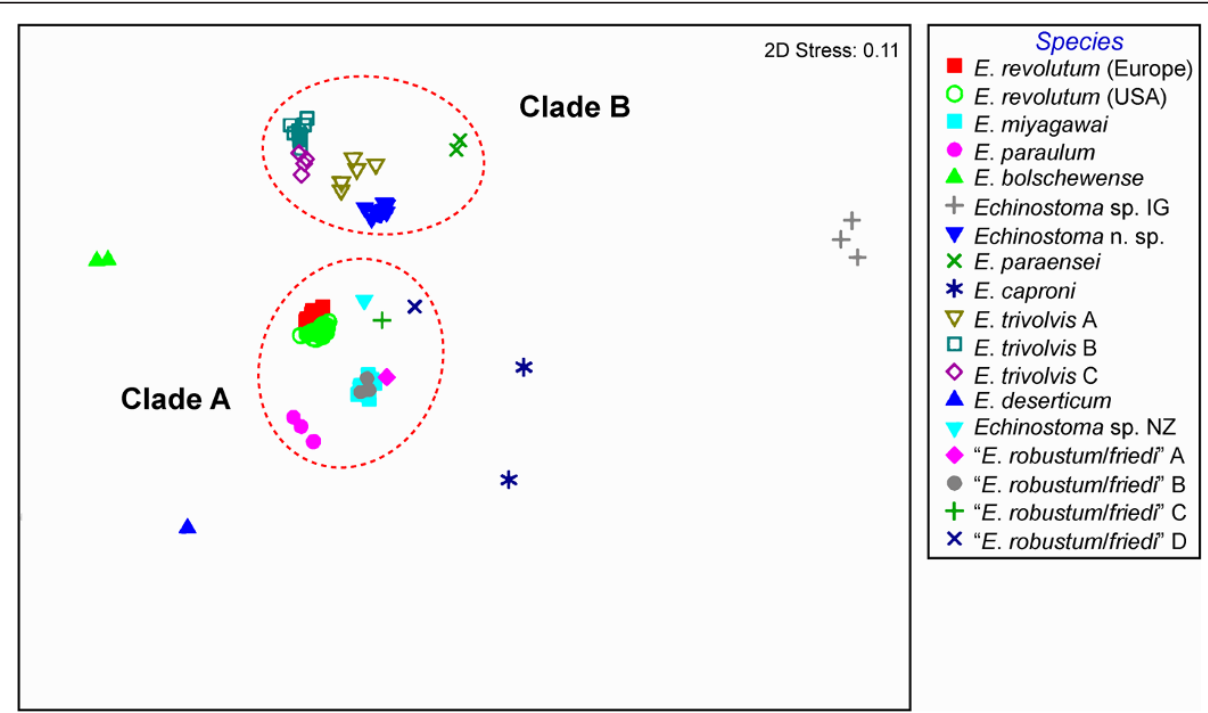

Figure 5 Non-metric multidimensional scaling ordination plot derived from the raw pairwise distances calculated for the nad 1 dataset. Labels for the lineages of E. trivolvis and "E. robustum/friedi" are after Detwiler et al. [16]. Ellipses indicate the two main clades. 


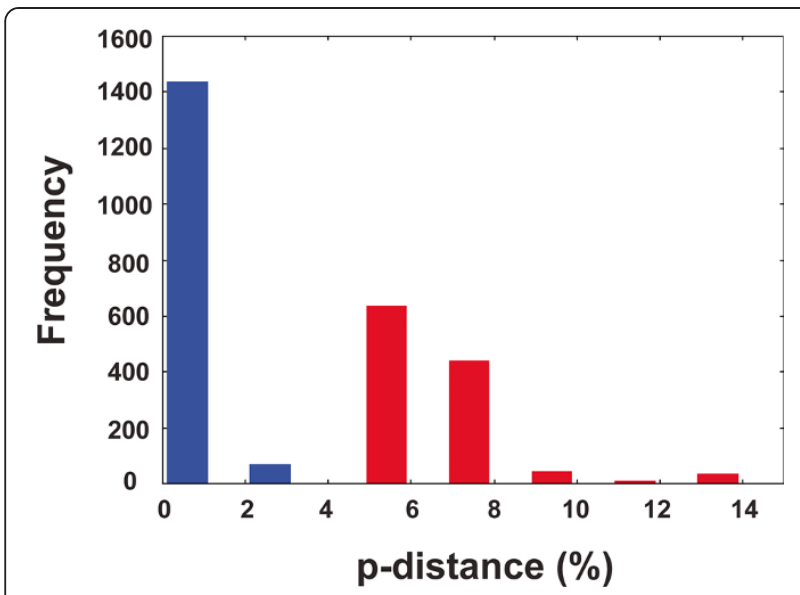

Figure 6 Patterns of intra- and interspecific divergence in Echinostoma spp. using the nad 1 dataset. Red bars indicate intraspecific divergence; blue bars indicate iterspecific divergence (raw p-distances in \%, pairwise comparisons between sister-species only).

genes, distance-based identification and morphological evidence. The integration of molecular and morphological data for two of the species-level lineages strongly indicates that these represent species new to science (see Georgieva et al. [19] for a description of the cercaria of Echinostoma sp. IG and Faltýnková et al. [46] for a description of the life-cycle stages of Echinostoma n. sp.).

Our extensive sampling resulted in a successful match of sequences based on life-cycle stages from naturally infected intermediate and definitive hosts for three of the European species whose life-cycles have been completed experimentally, E. revolutum, E. miyagawai and E. paraulum (see $[1,2,46]$ ). Notably, the identification of the adult isolates from natural infections based on morphology alone using the concept of Kostadinova et al. $[1,2,28]$ and the morphological data from adult experimental isolates, matched the identification using molecular data. Sequencing of isolates from wild mammalian hosts within Europe may contribute to resolving the natural definitive hosts in the life-cycles of $E$. bolschewense and Echinostoma n. sp. The large-scale sampling of natural snail populations also shed light on the intermediate host range of Echinostoma spp. Whereas E. bolschewense, E. miyagawai, E. paraulum and Echinostoma n. sp. were found to infect single first intermediate snail species (Viviparus acerosus, Planorbis planorbis, Lymnaea stagnalis and Planorbarius corneus, respectively), Echinostoma sp. IG was detected in two snail hosts (Radix auricularia and $R$. peregra) and E. revolutum (s. str.) exhibited the widest intermediate host range ( $L$. stagnalis, $R$. auricularia, $R$. peregra and Stagnicola palustris). These results further stress the importance of precise identification of cercarial isolates of Echinostoma spp. in hosts found to harbour more than one species: L. stagnalis (parasitised by two species, E. revolutum (s. str.) and E. paraulum), $R$. auricularia (E. revolutum (s. str.) and
Echinostoma sp. IG) and R. peregra (E. revolutum (s. str.) and Echinostoma sp. IG). As shown by Georgieva et al. [19] and Faltýnková et al. [46], these species combinations can be distinguished based on cercarial morphology.

Perhaps the most important result of our study is that the integration of morphological and molecular data from both experimental and wildlife infections clarified the status of E. revolutum (s. str.) and E. paraulum. Both species use $L$. stagnalis as the first intermediate host but the cercariae differ in the number and location of the paraoesophageal gland-cells. The cercarial isolates from L. stagnalis, with a pattern of paraoesophageal gland-cells dissimilar to E. revolutum and experimentally obtained and wild adult isolates, formed a distinct strongly-supported clade with "E. robustum/friedi" Lineages C and D of Detwiler et al. $[16,17]$ as nearest neighbours (Figure 1). A detailed examination of adult morphology (experimental set and the voucher specimen from natural infection used for sequencing; see [46]) confirmed their identification as E. paraulum, a species long considered a synonym of E. revolutum (see e.g. $[4,5])$. Combining morphological and molecular evidence from different life-cycle stages, we can confidently restore the validity of this species. All life-cycle stages of E. revolutum (s. str.) and E. paraulum linked to the sequences from Europe reported here are described in detail by Faltýnková et al. [46].

Our study provided the first datasets of sequences for E. miyagawai and E. bolschewense. Echinostoma miyagawai was re-validated after experimental completion of its life-cycle and detailed re-description of the morphology of all stages based on European material [1,2]; however, no sequences for this species were available. The incorporation of a large set of sequences for larval and adult $E$. miyagawai in our analyses solved the taxonomy of the German and Australian isolates identified as E. revolutum by Morgan \& Blair [14,26]. Kostadinova et al. [28] examined a single voucher specimen (Australian isolate PMeta-2) of Morgan \& Blair [14] and concluded that the morphology of this adult worm suggests an affiliation to E. robustum. However, they stated "... at present we prefer not to favour this specific identification for the 'Australian-German' clade of Echinostoma sp., pending a redescription of both larval and adult stages". The inclusion of the sequences for four of the " $E$. revolutum" isolates of Morgan \& Blair [14,26] within the wellsupported clade of E. miyagawai (containing both cercarial and adult isolates identified using the concept of Kostadinova et al. [1,2]) suggests that these, in fact, belong to the latter species. The "German" isolate of " $E$. revolutum" (a laboratory strain identified by I. Kanev and sequenced by Morgan \& Blair [14,25,26]) clearly represents a misidentification. As shown by Kostadinova et al. [1] based on re-examination of the voucher material, the re-description of E. revolutum by Kanev [5] was 
based on a mixture of material and likely represents a composite of at least two species of the 'revolutum' group. The position of E. friedi of Marcilla et al. (Valencia, Spain; AJ564379; published in GenBank only) within the E. miyagawai clade supports the inclusion of this species among the synonyms of E. miyagawai. Moreover, "E. revolutum Germany, Europe" of Morgan \& Blair [14,26] (AF025832) and E. friedi (Valencia, Spain; AJ564379) represented a haplotype shared with adult isolates of E. miyagawai ex An. platyrhynchos from Poland and Ay. fuligula from the Czech Republic. The close association of $E$. friedi with the Australian isolates of Morgan \& Blair [14,26] listed above was also confirmed in the recent study of Detwiler et al. [16] on a different set of taxa. However, a mislabelling of the sequence for E. friedi of Marcilla et al. (AJ564379) as the sequence for an isolate of Kostadinova et al. [28] provisionally identified as E. cf. friedi (AY168937) leaves a wrong impression that the latter isolate also represents $E$. friedi (see Georgieva et al. [19] for detailed discussion). As shown by Georgieva et al. [19] and the present study, the isolate of Kostadinova et al. [28] belongs to an as yet undescribed species of Echinostoma (Echinostoma sp. IG); this is strongly supported in the present analyses.

The life-cycle of Echinostoma bolschewense (possible synonym E. jurini (Skvortsov, 1924) of Kanev et al. [7]; for detailed comment on taxonomy see Faltýnková et al. [46]) has been elucidated by Našincová [21] who described in detail the life-cycle stages (rediae and cercariae from naturally infected prosobranch snails, Viviparus contectus, metacercariae from a range of prosobranch and pulmonate snails and adults from hamsters) of this species. To the best of our knowledge, this is the only species of Echinostoma developing in prosobranch snails; our study elucidated another first intermediate host, Viviparus acerosus.

In addition to the large nad 1 dataset, we also generated $28 \mathrm{~S}$ rDNA sequences for the six European species of the 'revolutum' group; these can be used in future phylogenetic studies at the supraspecific level. The minima for sequence divergence (0.25-0.41\%) between Echinostoma spp. for which $28 \mathrm{~S}$ rDNA data were available are comparable with the minima observed between closely related but distinct digenean species (e.g. $0.2-0.4 \%$ in the Cryptogonimidae, see Miller \& Cribb $[51,52]$.

\section{American species within the 'revolutum' group}

The taxonomy of the American species of Echinostoma belonging to the 'revolutum' group is in urgent need of revision. First, consistent with the recent study of Georgieva et al. [19], we found strong evidence for genetic differentiation between the North American and European populations within E. revolutum (s.l.) as evidenced by the phylogenetic reconstructions and distance-based identification. Therefore, the increased sampling within Europe reinforces the results of the network analysis of
E. revolutum (s.l.) indicating lack of gene flow between Europe and North America [16].

Secondly, although the nad 1 dataset was substantially expanded, the same lineages of E. trivolvis and "E. robustum/friedi" were recovered as identified by Detwiler et al. $[16,17]$ suggesting that the lineages within E. trivolvis (A-C) and "E. robustum/friedi" (A, C and D) sensu Detwiler et al. [16] may represent distinct, closely-related cryptic species. However, this finding calls for further molecular and taxonomic scrutiny. In particular, comprehensive sampling in both North and South America is required to enlarge the sample size for the three lineages of "E. robustum/friedi" (note that this label is no more appropriate in view of the synonymy indicated above; we use it just for consistency in referring to the isolates of Detwiler et al. [16,17] currently represented by singletons). This would provide data for testing the monophyly of the lineages and alternative hypotheses for patterns of diversification associated with e.g. specificity to the snail host or geography. The strong support for different sister-group relationships of the three isolates of "E. robustum/friedi" further reinforce our suggestion; it is also worth noting that one of the isolates (Lineage D) originates from naturally infected Biomphalaria glabrata in South America (Brazil; see Detwiler et al. [16], whereas the other two (Lineages A and C) represent cercarial isolates ex Lymnaea elodes in the USA. It is also necessary to test if the structuring inferred from the nad 1 sequences (Detwiler et al. [16,17]; this study) is reflected in divergences in the nuclear genes and consistent differences in morphology.

Although species boundaries are delimited, naming the American species would appear the most complicated task. Five nominal species assigned by different authors to the 'revolutum' group have been described in North America (USA), i.e. Echinostoma armigerum; E. callawayense Barker \& Noll in Barker, 1915; E. coalitum; E. trivolvis and Echinoparyphium contiguum Barker \& Barston in Barker, 1915 [6,53,54], and further eight species have been described in South America (Brazil), i.e. E. barbosai; E. erraticum Lutz, 1924; E. luisreyi Maldonado, Vieira \& Lanfredi, 2003; E. microrchis Lutz, 1924; E. neglectum Lutz, 1924; E. nephrocystis Lutz, 1924; E. rodriguesi Hsu, Lie \& Basch, 1968; E. paraensei Lie \& Basch, 1967 [24,55-59]. In contrast to the opinions of Beaver [4] and Kanev et al. [6] regarding the synonymy of all North American species listed above with E. trivolvis, detailed studies on the morphology of some of the South American species have revealed that these exhibit distinguishing differences $[18,24,57,59]$. Comparative approaches to the morphology of North American strains of "E. revolutum" and E. trivolvis during the 'pre-molecular era' have shown that morphometric features of the experimentally raised adult worms can be used to distinguish closely related species $[60,61]$. 
Therefore, although the sequence information and analyses of Detwiler et al. $[16,17]$ and the present study provide a sound framework for alpha taxonomy, revealing the species diversity of the 'revolutum' group of Echinostoma in the Americas requires an integrative approach linking the molecular data with detailed phenotypical characterisation of the isolates studied. Although the species within this group qualify as cryptic, the comprehensive morphological analysis in the course of our study revealed useful features for distinguishing two life-cycle stages, cercariae and adults, of the European Echinostoma spp. (Faltýnková et al. [46]; see also [19]). This stresses the importance of detailed morphological examination of live cercarial isolates prior to sequencing and the availability of voucher specimens identified by experts for the adult isolates sequenced (e.g. present study - see Faltýnková et al. [46]; Maldonado et al. [18]). The latter, even if unidentified at the time of DNA sequence publication, are of primary importance for accelerating further integrative taxonomy studies. Unfortunately, although a large number (32) of adult specimens of "E. revolutum", E. trivolvis (Lineages $\mathrm{A}-\mathrm{C}$ ) and "E. robustum/friedi" (Lineage D) (see Additional file 1: Table S1) from natural infections or raised experimentally were sequenced by Detwiler et al. [16,17], these have not been submitted to a museum collection.

\section{Asian species within the 'revolutum' group}

Several notes of caution are required before considering the recent papers on "Echinostoma" spp. reported recently from Asian locations (Saijuntha et al. [62-64]; Noikong et al. [65]). First, the authors should be aware that annotations in GenBank solely reflect the identification (in most cases not supported by voucher material and/or morphological data) of the authors submitting the sequences. Whereas the identifications based on comparisons with original species descriptions may be correct, failure to follow the subsequent taxonomic/systematic changes may results in 'discoveries' such as "Interestingly, this study revealed that $E$. revolutum was more closely aligned with $E$. recurvatum than the other species of genus Echinostoma (e.g., E. malayanum), contradicting traditional morphological taxonomy." (Saijuntha et al. [63]) and "Interestingly, this study revealed that two species of genus Echinostoma, i.e. E. revolutum and E. malayanum do not cluster as a monophyletic clade and/or sister taxa." (Saijuntha et al. [62]). Just reading the subtitle for this species in the taxonomic revision of Kostadinova \& Gibson [66], i.e. "Artyfechinostomum malayanum (Leiper, 1911) Railliet, 1925 [Syns Echinostoma malayanum Leiper, 1911; Euparyphium malayanum (Leiper, 1911) Leiper, 1915; Echinoparyphium malayanum (Leiper, 1911) Skrjabin \& Shul'ts, 1929]" makes it clear that E. malayanum has been transferred to the genus Artyfechinostomum Lane, 1915 by Railliet nearly a century ago and that the only different generic placements of this species are those of Leiper (in Euparyphium) and Skrjabin \& Shul'ts (in Echinoparyphium). Therefore, there is nothing "contradicting traditional morphological taxonomy" since the clustering pattern in Saijuntha et al. [62] simply reflects a distinction at the generic level which the authors failed to recognise because of lack of knowledge on the taxonomy of the group. Along this line, Echinostoma hortense Asada, 1926 has been transferred to the genus Isthmiophora as I. hortensis (Asada, 1926) in the revision of Kostadinova \& Gibson [66]. The examination of the experimental material of $E$. hortense used for obtaining the sequence data of Morgan \& Blair [14,25,26] confirmed its affiliation to Isthmiophora (see Kostadinova et al. [28]). However, this species is still referred to as E. hortense by Saijuntha et al. [62] and Noikong et al. [65].

A second problem in recent studies on Asian echinostomatids is the failure to understand/integrate existing knowledge (e.g. re-identifications of sequenced isolates based on morphological evidence, e.g. Echinoparyphium ellisi (AF026791, isolate PMeta3 of Morgan \& Blair [14,26]) and Echinoparyphium hydromyos (AF026290, isolate Rat-Ad of Morgan \& Blair [14]) re-identified by Kostadinova et al. [28] based on examination of the available voucher material, are still being referred to as "Echinostoma sp." (see Noikong et al. [65]).

Thirdly, there are wrong interpretations of published work, e.g. "These results were relatively concordant to a previous report by Kostadinova et al., 2003, which confirmed that not all species within the genus Echinostoma represent a monophyletic group." (Saijuntha et al. [62]). In fact, the opening sentence of the section "Molecular identification and relationships between Echinostoma, Echinoparyphium, Hypoderaeum and Isthmiophora" in Kostadinova et al. [28] states: "Considering the initial identification (as given by Morgan \& Blair, 1998a, b) and the names of the taxa as existing at present in the GenBank database (our emphasis), Echinostoma is represented as a paraphyletic taxon with Echinoparyphium recurvatum (ITS and ND1 trees) and Isthmiophora melis (ND1 trees), Echinoparyphium aconiatum (ND1 trees) and Hypoderaeum conoideum (ND1 trees) nested within it." [28]. Unfortunately, the findings of the study of Kostadinova et al. [28] were not understood by Saijuntha et al. [62].

Fourthly, the original papers should be consulted in order that the correct origin of the material sequenced is identified. For example, Saijuntha et al. [63] assumed that the sequence U58102 of Morgan \& Blair [25] was of an "Australian isolate". The provenance of this isolate is not annotated in GenBank but is clearly identified (i.e. Germany, Europe) in the original papers (see Table 1 in Morgan \& Blair [25,26], respectively). The status of this isolate was discussed by Kostadinova et al. [28] who 
suggested a provisional identification as Echinostoma cf. robustum based on the additional molecular data. Failure to detect the origin of this isolate has resulted in a wrong conclusion, i.e. "Moreover, the phylogenetic relationships of $E$. revolutum presented in the present study suggested that genetic clustering is related to the geographical origin of the isolates, i.e., the American isolates closely aligned to the European isolate, whereas the Australian isolate closely aligned to Southeast Asian isolates." (Saijuntha et al. [63]). In fact, the isolate of "E. revolutum" from Thailand exhibits close affinity to the European isolate studied by Morgan \& Blair $[14,26]$, which we have shown to represent $E$. miyagawai (see above). Finally, to our astonishment we found out that not a single sequence has been deposited in GenBank from the sequencing study in Thailand by Noikong et al. [65]. The lack of evidence for further comparative evaluation renders the findings reported by these authors useless.

Overall, these problems with the recent molecular studies based on Asian echinostomatids result in a rather bleak picture with regard to the identity of the isolates sequenced. It is likely that the papers by Saijuntha and colleagues deal with two species of the 'revolutum' group, one misidentified as E. revolutum and one misidentified as " $E$. recurvatum $43-50$ collar spines" (E. recurvatum is a species with 45 collar spines), both exhibiting affinities with $E$. miyagawai. Whereas the identification of Artyfechinostomum malayanum (as Echinostoma malayanum in their papers) may be correct, that of "Hypoderaeum conoideum 41-45 collar spines" is likely wrong. Species of Hypoderaeum possess 43-82 collar spines [67] so that the minimum number of spines provided for the isolate (i.e. 41-45) is probably a miscount. Further, $H$. conoideum is characterised by the possession of 47-53 spines [68], i.e. above the range given by Saijuntha et al. [62]. Unfortunately, no data other than a short $\operatorname{cox} 1$ (250 nt) sequence are available to check their identification of " $H$. conoideum". All these considerations indicate that further molecular work based on precise identification of the Asian isolates associated with the description and deposition of vouchers is required in order to make progress in elucidating the species diversity of the 'revolutum' group in Asia.

\section{Nad1 for a barcode?}

The first assessment of the usefulness of the partial mitochondrial nad1 gene sequences for species identification and inferring the relationships within the 'revolutum' group was carried out in a comparative framework by Morgan \& Blair [26]. Their findings suggested that nad 1 is diverging significantly faster than the cox 1 and ITS gene regions and thus appears to be the most informative region. These authors reported interspecific sequence divergence for nad 1 within the 'revolutum' group of $12.3-30.8 \%$ [26] and 9.6-30.8\% [14]. However, the very high upper limits of these ranges were due to inclusion in their comparisons of "Echinostoma" hortense, which was shown to belong to a different echinostomatid genus, Isthmiophora [66]. Detwiler et al. [16] reported a range of $1.2-5.4 \%$ and $8.1-12.4 \%$ for nad 1 mean intra- and interspecific genetic divergence, respectively, for three sibling species groups of the 'revolutum' complex designated as "E. revolutum", E. trivolvis (Lineages A-C) and "E. robustum/friedi" (Lineages A-D).

These values are generally comparable to the ranges obtained in our study (i.e. means of $0.2-1.8 \%$ and $2.7-$ $19.4 \%$, respectively), the mean pairwise divergence within the named and putative species in the present expanded dataset being much lower than the data reported by Detwiler et al. [16]. Although nad1 differentiation within species-level lineages was generally low compared with divergences between species with cases where the same haplotype was detected in remote geographical locations [E. revolutum (s. str.) and E. miyagawai], the overall mean interspecific divergence was 16 -fold higher than the mean intraspecific divergence. The molecular divergences among three sister-species groups (i.e. E. trivolvis Lineages A-C; E. miyagawai - "E. robustum/friedi" Lineage A; E. revolutum (s. str.) (Europe) - "E. revolutum" (USA)) were relatively low (range for means 2.7-8.6\%). However, a barcode gap (i.e. a discontinuity in levels of intraspecific compared with interspecific genetic divergence) was detected and all sister-species groups could be resolved using diagnostic nucleotide sites.

\section{Conclusion}

Taking into account that a large comparative database of sequences exists, we conclude that nad 1 should be the first choice for large-scale barcode-based identification of the species of the 'revolutum' group of Echinostoma. Our study provides a comprehensive reference library for precisely identified isolates of the European species and highlights the importance of an integrative approach for species identification linking molecular, morphological and biological data.

\section{Additional file}

Additional file 1: Summary data for nad1 sequences of Echinostoma spp. retrieved from the GenBank.

Competing interests

The authors declare that they have no competing interests.

Authors' contributions

AK and AF: conceived and designed the study, discussed the results and helped draft the MS. AF, MS, SG and JS: obtained samples, discussed the results and took part in the preparation of the MS. AF, MS, SG and RB: undertook the identification and morphological characterisation of the isolates. RB and IB-C contributed to sequencing and drafting the results. SG 
carried out the major part of the sequencing, performed the phylogenetic analyses and prepared the first draft of the MS. TS coordinated the project, discussed the results and helped draft the MS. All authors read and approved the final manuscript.

\section{Acknowledgements}

This study was funded by the Czech Science Foundation (projects P505/10/ 1562 and P505/12/G112) and the Institute of Parasitology (RVO 60077344). We thank two anonymous reviewers for their comments on the manuscript

\section{Author details}

${ }^{1}$ Institute of Parasitology, Biology Centre of the Academy of Sciences of the Czech Republic, Branišovská 31, 37005 České Budějovice, Czech Republic. ${ }^{2}$ Faculty of Science, University of South Bohemia, Branišovská 31, 37005 České Budějovice, Czech Republic. ${ }^{3}$ College of Medical, Veterinary and Life Sciences, University of Glasgow, Glasgow G12 8QQ, UK. ${ }^{4}$ Natural History Museum of Geneva, P.O. Box 6134, CH-1211 Geneva, Switzerland. 'Komenský Museum, Horní nám, 7, 75011 Přerov 2, Přerov, Czech Republic.

Received: 28 September 2014 Accepted: 4 November 2014 Published online: 27 November 2014

\section{References}

1. Kostadinova A, Gibson Dl, Biserkov V, Chipev N: Re-validation of Echinostoma miyagawai Ishii, 1932 (Digenea: Echinostomatidae) on the basis of experimental completion of its life-cycle. Syst Parasitol 2000, 45:81-108.

2. Kostadinova A, Gibson DI, Biserkov V, Ivanova R: A quantitative approach to the evaluation of the morphological variability of two echinostomes, Echinostoma miyagawai Ishii, 1932 and E. revolutum (Frölich, 1802) from Europe. Syst Parasitol 2000, 45:1-15.

3. Kostadinova A, Gibson DI: The Systematics of the Echinostomes. In Echinostomes as Experimental Models for Biological Research. Edited by Fried B, Graczyk TK. Dordrecht: Kluwer Academic Publishers; 2000:31-57.

4. Beaver PC: Experimental studies on Echinostoma revolutum (Frölich) a fluke from birds and mammals. III Biol Monogr 1937, 15:7-96.

5. Kanev I: Life-cycle, delimitation and redescription of Echinostoma revolutum (Frölich, 1802) (Trematoda: Echinostomatidae). Syst Parasitol 1994, 28:125-144.

6. Kanev I, Dimitrov V, Radev V, Fried B: Redescription of Echinostoma trivolvis (Cort, 1914) with a discussion of its identity. Syst Parasitol 1995, 32:61-70.

7. Kanev I, Fried B, Dimitrov V, Radev V: Redescription of Echinostoma jurini (Skvortzov, 1924) with a discussion of its identity and characteristics. Ann Naturhist Mus Wien 1995, 97B:37-53.

8. Kosupko GA: [The morphological peculiarities of Echinostoma revolutum and E. miyagawai cercariae.]. Trudy VIGIS 1969, 15:159-165. In Russian.

9. Kosupko GA: New data on the bioecology and morphology of Echinostoma revolutum and E. miyagawai (Trematoda: Echinostomatidae). Byull VIGIS 1971, 5:43-49 (In Russian).

10. Kosupko GA: [Criteria of the species Echinostoma revolutum, demonstrated on experimental material.]. In Sbornik rabot po gel'mintologii posvyashchen 90-letiyu so dnya rozhdeniya akademika K.I. Skryabina. Moscow: 'Kolos'; 1971:167-175. In Russian.

11. Kosupko GA: [Morphology and Biology of Echinostoma revolutum Frölich, 1802 and Echinostoma miyagawai Ishii, 1932 (Trematoda: Echinostomatidae) Studied on Experimental Material.], PhD Thesis. Moscow: VIGIS; 1972. In Russian.

12. Našincová $\mathrm{V}$ : Contribution to the distribution and the life history of Echinostoma revolutum in Central Europe. Věst Českoslov Společ Zool 1986, 50:70-80

13. Kostadinova A: Echinostoma echinatum (Zeder, 1803) sensu Kanev (Digenea: Echinostomatidae): a note of caution. Syst Parasitol 1995, 32:23-26.

14. Morgan JAT, Blair D: Mitochondrial ND1 gene sequences used to identify echinostome isolates from Australia and New Zealand. Int J Parasitol 1998, 28:493-502.

15. Sorensen RE, Kanev I, Fried B, Minchella DJ: The occurrence and identification of Echinostoma revolutum from North American Lymnaea elodes snails. J Parasitol 1997, 83:169-170.

16. Detwiler JT, Bos DH, Minchella DJ: Revealing the secret lives of cryptic species: examining the phylogenetic relationships of echinostome parasites in North America. Mol Phylogenet Evol 2010, 55:611-620.
17. Detwiler JT, Zajac AM, Minchella DJ, Belden LK: Revealing cryptic parasite diversity in a definitive host: echinostomes in muskrats. J Parasitol 2012 98:1148-1155

18. Maldonado A Jr, Locker ES, Morgan JAT, Rey L, Lanfredi RM: Description of the adult worms of a new Brazilian isolate of Echinostoma paraensei (Platyhelminthes: Digenea) from its natural vertebrate host Nectomys squamipes by light and scanning electron microscopy and molecular analysis. Parasitol Res 2001, 87:840-848.

19. Georgieva S, Selbach C, Faltýnková A, Soldánová M, Sures B, Skírnisson K Kostadinova A: New cryptic species of the 'revolutum' group of Echinostoma (Digenea: Echinostomatidae) revealed by molecular and morphological data. Parasit Vectors 2013, 6:64.

20. Našincová V: [Trematode developmental stages in Czech aquatic snails and life-cycles of selected species of the family Omphalometridae and Echinostomatidae], PhD Thesis. České Budějovice: Institute of Parasitology, Czechoslovak Academy of Sciences; 1992. In Czech.

21. Našincová V: The life cycle of Echinostoma bolschewense (Kotova, 1939) (Trematoda: Echinostomatidae). Folia Parasitol 1991, 38:143-154.

22. Toledo R, Muñoz-Antolí C, Esteban JG: The life-cycle of Echinostoma friedi n. sp. (Trematoda: Echinostomatidae) in Spain and a discussion on the relationships within the 'revolutum' group based on cercarial chaetotaxy. Syst Parasitol 2000, 45:199-217.

23. Kechemir N, Jourdane J, Mas-Coma S: Life cycle of a new African echinostome species reproducing by parthenogenesis. J Nat Hist 2002, 36:1777-1784.

24. Maldonado A Jr, Vieira GO, Lanfredi RM: Echinostoma luisreyi n. sp. (Platyhelminthes: Digenea) by light and scanning electron microscopy. J Parasitol 2003, 89:800-808.

25. Morgan JAT, Blair D: Nuclear rDNA ITS sequence variation in the trematode genus Echinostoma: an aid to establishing relationships within the 37-collar-spine group. Parasitology 1995, 111:609-615.

26. Morgan JAT, Blair D: Relative merits of nuclear ribosomal internal transcribed spacers and mitochondrial CO1 and ND1 genes for distinguishing among Echinostoma species (Trematoda). Parasitology 1998, 116:289-297.

27. Sorensen RE, Curtis J, Minchella DJ: Intraspecific variation in the rDNA ITS loci of 37-collar-spined echinostomes from North America: implications for sequence-based diagnoses and phylogenetics. J Parasitol 1998, 84:992-997.

28. Kostadinova A, Herniou EA, Barrett J, Littlewood DTJ: Phylogenetic relationships of Echinostoma Rudolphi, 1809 (Digenea:

Echinostomatidae) and related genera re-assessed via DNA and morphological analyses. Syst Parasitol 2003, 54:159-176.

29. Blouin MS: Molecular prospecting for cryptic species of nematodes: mitochondrial DNA versus internal transcribed spacer. Int J Parasitol 2002, 32:527-531.

30. Faltýnková A, Našincová $V$, Kablásková L: Larval trematodes (Digenea) of the great pond snail, Lymnaea stagnalis (L.) (Gastropoda, Pulmonata), in Central Europe: a survey of species and key to their identification. Parasite 2007, 14:39-51.

31. Faltýnková A, Našincová $V$, Kablásková L: Larval trematodes (Digenea) of planorbid snails (Gastropoda: Pulmonata) in Central Europe: a survey of species and key to their identification. Syst Parasitol 2008, 69:155-178.

32. Tkach $\vee$, Pawlowski J: A new method of DNA extraction from the ethanol-fixed parasitic worms. Acta Parasitol 1999, 44:147-148.

33. Lockyer AE, Olson PD, Littlewood DTJ: Utility of complete large and small subunit rRNA genes in resolving the phylogeny of the Neodermata (Platyhelminthes): implications and a review of the cercomer theory. Biol J Linn Soc Lond 2003, 78:155-171.

34. Bray RA, Waeschenbach A, Cribb TH, Weedall GD, Dyal P, Littlewood DTJ: The phylogeny of the Lepocreadioidea (Platyhelminthes, Digenea) inferred from nuclear and mitochondrial genes: Implications for their systematics and evolution. Acta Parasitol 2009, 54:310-329.

35. Tkach W, Littlewood DTJ, Olson PD, Kinsella JM, Swiderski Z: Molecular phylogenetic analysis of the Microphalloidea Ward, 1901 (Trematoda: Digenea). Syst Parasitol 2003, 56:1-15.

36. Tamura K, Stecher G, Peterson D, Filipski A, Kumar S: MEGA6: molecular evolutionary genetics analysis version 6.0. Mol Biol Evol 2013, 30:2725-2729.

37. Telford MJ, Herniou EA, Russell RB, Littlewood DTJ: Changes in mitochondrial genetic codes as phylogenetic characters: two examples from the flatworms. Proc Natl Acad Sci U S A 2000, 97:11359-11364. 
38. Ronquist F, Teslenko M, van der Mark P, Ayres DL, Darling A, Hohna S, Larget B, Liu L, Suchard MA, Huelsenbeck JP: MrBayes 3.2: efficient Bayesian phylogenetic inference and model choice across a large model space. Syst Biol 2012, 61:539-542.

39. Guindon S, Gascuel O: A simple, fast and accurate method to estimate large phylogenies by maximum-likelihood. Syst Biol 2003, 52:696-704.

40. Darriba D, Taboada GL, Doallo R, Posada D: jModelTest 2: more models, new heuristics and parallel computing. Nat Methods 2012, 9:772

41. Rambaut A, Drummond AJ: Tracer v1.4.; 2007. Available from http://beast. bio.ed.ac.uk/Tracer.

42. Huelsenbeck JP, Ronquist F, Nielsen R, Bollback JP: Bayesian inference of phylogeny and its impact on evolutionary biology. Science 2001, 294:2310-2314

43. Clarke KR, Gorley RN: PRIMER v6: User Manual/Tutorial. Plymouth, Devon, UK: PRIMER-E Ltd; 2006.

44. Meier RK, Shiyang G, Vaidya PKLN: DNA barcoding and taxonomy in diptera: a tale of high intraspecific variability and low identification success. Syst Biol 2006, 55:715-728.

45. Clement M, Posada D, Crandall KA: TCS: a computer program to estimate gene genealogies. Mol Ecol 2000, 9:1657-1660.

46. Faltýnková A, Georgieva S, Soldánová M, Kostadinova A: A re-assessment of species diversity within the 'revolutum' group of Echinostoma Rudolphi, 1809 (Digenea: Echinostomatidae) in Europe. Syst Parasitol 2015, 1:1-25.

47. Olson PD, Cribb TH, Tkach W, Bray RA, Littlewood DTJ: Phylogeny and classification of the Digenea (Platyhelminthes: Trematoda). Int J Parasitol 2003, 33:733-755

48. Hebert PDN, Stoeckle MY, Zelmak TS, Francis CM: Identification of birds through DNA barcodes. PLoS Biol 2004, 2:1657-1663.

49. Lotfy WM, Brant SV, DeJong RJ, Le TH, Demiaszkiewicz A, Rajapakse RP, Perera VB, Laursen JR, Loker ES: Evolutionary origins, diversification, and biogeography of liver flukes (Digenea, Fasciolidae). Am J Trop Med Hyg 2008, 79:248-255.

50. Mollaret I, Jamieson BG, Adlard RD, Hugall A, Lecointre G, Chombard C, Justine J-L: Phylogenetic analysis of the Monogenea and their relationships with Digenea and Eucestoda inferred from 28S rDNA sequences. Mol Biochem Parasitol 1997, 90:433-438.

51. Miller TL, Cribb TH: Two new cryptogonimid genera (Digenea, Cryptogonimidae) from Lutjanus bohar (Perciformes, Lutjanidae): analyses of ribosomal DNA reveals wide geographic distribution and presence of cryptic species. Acta Parasitol 2007, 52:104-113.

52. Miller TL, Cribb TH: Coevolution of Retrovarium n. gen. (Digenea: Cryptogonimidae) in Lutjanidae and Haemulidae (Perciformes) in the Indo-West Pacific. Int J Parasitol 2007, 37:1023-1045.

53. Barker F: Parasites of the American muscrat (Fiber zibethicus). J Parasitol 1915, 1:184-197.

54. Cort WW: Larval trematodes from North American freshwater snails (Preliminary report). J Parasitol 1914, 1:65-84.

55. Lutz A: Estudos sobre a evoluacão dos endotrematodes brazileiros. Mem Inst Oswaldo Cruz 1924, 17:55-93.

56. Lie KJ, Basch PF: Life history of Echinostoma barbosai sp. n. (Trematoda: Echinostomatidae). J Parasitol 1966, 52:1052-1057.

57. Lie KJ, Basch PF: The life history of Echinostoma paraensei sp. $\mathrm{n}$. (Trematoda: Echinostomatidae). J Parasitol 1967, 53:1192-1199.

58. Hsu KC, Lie KJ, Basch PF: The life history of Echinostoma rodriguesi sp. $\mathrm{n}$. (Trematoda: Echinostomatidae). J Parasitol 1968, 54:333-339.

59. Kohn A, Fernandes BMM: Sobre as especies do genero Echinostoma Rudolphi, 1809 decritas por Adolpho Lutz em 1924. Mem Inst Oswaldo Cruz 1975, 73:77-89.

60. Fried B, Mueller TJ, Frazer BA: Observations on Echinostoma revolutum and Echinostoma trivolvis in single and concurrent infections in domestic chicks. Int J Parasitol 1997, 27:1319-1322.

61. Humphries JE, Reddy A, Fried B: Infectivity and growth of Echinostosma revolutum (Frölich, 1802) in the domestic chick. Int J Parasitol 1997, 27:129-130.

62. Saijuntha W, Sithithaworn P, Duenngai K, Kiatsopit N, Andrews RH, Petney TN: Genetic variation and relationships of four species of medically important echinostomes (Trematoda: Echinostomatidae) in South-East Asia. Infect Genet Evol 2011, 11:375-381.

63. Saijuntha W, Tantrawatpan C, Sithithaworn P, Andrews RH, Petney TN: Genetic characterization of Echinostoma revolutum and Echinoparyphium recurvatum (Trematoda: Echinostomatidae) in Thailand and phylogenetic relationships with other isolates inferred by ITS1 sequence. Parasitol Res 2011, 108:751-755.

64. Saijuntha W, Tantrawatpan C, Sithithaworn P, Andrews RH, Petney TN: Spatial and temporal genetic variation of Echinostoma revolutum (Trematoda: Echinostomatidae) from Thailand and the Lao PDR. Acta Trop 2011, 118:105-109.

65. Noikong W, Wongsawad C, Chai J-Y, Saenphet S, Trudgett A: Molecular analysis of echinostome metacercariae from their second intermediate host found in a localised geographic region reveals genetic heterogeneity and possible cryptic speciation. PLoS Negl Trop Dis 2014, 8(4):e2778. doi:10.1371/journal. pntd.0002778.

66. Kostadinova A, Gibson Dl: Isthmiophora Lühe, 1909 and Euparyphium Dietz, 1909 (Digenea: Echinostomatidae) re-defined, with comments on their nominal species. Syst Parasitol 2002, 52:205-217.

67. Kostadinova A: Family Echinostomatidae. In Keys to the Trematoda, Volume 2. Edited by Jones A, Bray RA, Gibson DI. London, UK: CAB International, Wallingford \& The Natural History Museum; 2005:9-64.

68. Skrjabin Kl, Bashkirova EY: Family echinostomatidae. Osnovy Trematodologii 1956, 12:53-930 (In Russian).

doi:10.1186/s13071-014-0520-8

Cite this article as: Georgieva et al: Echinostoma 'revolutum' (Digenea: Echinostomatidae) species complex revisited: species delimitation based on novel molecular and morphological data gathered in Europe. Parasites \& Vectors 2014 7:520.

\section{Submit your next manuscript to BioMed Central and take full advantage of:}

- Convenient online submission

- Thorough peer review

- No space constraints or color figure charges

- Immediate publication on acceptance

- Inclusion in PubMed, CAS, Scopus and Google Scholar

- Research which is freely available for redistribution

Submit your manuscript at www.biomedcentral.com/submit
C) Biomed Central 